\title{
GLOBAL LNG TRADE: A COMPREHENSIVE AND UP TO DATE ANALYSIS
}

\author{
Hamed Nikhalat-Jahromi ${ }^{a}, *$; Panagiotis Angeloudis ${ }^{b}$; Michael G. H. Bell ${ }^{c}$; Robert A. Cochrane ${ }^{b}$ \\ ${ }^{a}$ Management Consultant in Oil \& Gas Industry, United Arab Emirates \\ ${ }^{b}$ Institute of Transport and Logistics Studies, University of Sydney, Australia \\ ${ }^{c}$ Port Operations Research and Technology Centre, Imperial College London, United Kingdom
}

\begin{abstract}
LNG) in global gas trade has grown steadily over the past decades; the paper focuses on this significant form of energy and provides an exhaustive portrait of its trade internationally. LNG trade flows both regionally and by country are described and the future of trade is forecast. Based on the description of trade flows, the business structure is discussed. The traditional LNG trade on long-term contracts (LTCS) is considered and it is explained how vital these contracts are in distributing the volume and price risks in the industry, furthermore, in securing finance for the LNG projects. The essence of gas market liberalization and its effect on LTCs is considered, it is shown that in liberalized gas markets, risk has migrated to upstream. In the light of this risk redistribution, the suppliers' intent in moving toward vertical integration of the industry is discussed. Next, various types of LNG spot sale in arbitrage and for uncommitted product to LTCs are considered and the biggest spot sale markets are identified. Finally, pricing of LNG for different markets in both LTCs and spot sales is discussed and it is forecast that due to the surge of supply rather than any change in oil prices, the LNG prices are anticipated to decrease globally at least for the next five years.
\end{abstract}

KEYWORDS: LNG; long-term contract; market liberalization; spot sale; pricing

\section{INTRODUCTION}

Natural gas is the world's third largest source of primary energy; it supplies around $20 \%$ of globe's primary energy (EIA, 2011). It has been embraced by governmental policy makers as a favoured energy resource in recent decades. A key reason for this is that only one-third of the world's gas reserves are in the politically unstable Middle East, whereas about two-thirds of the world's oil reserves lie there (UBS, 2004). In addition, natural gas is efficient and environmentally friendly (Weems and Hwang, 2013). According to BP (2014), about one-third of gas produced in 2013 was exported internationally; this is $1,035.9$ billion cubic meters (BCM) of gas exported. There are two means of exporting gas internationally: using pipelines, and by sea in its liquid form known as LNG. Generally, liquefying natural gas and shipping it via ocean vessels becomes cheaper than pumping through off-shore pipelines if the market is farther than about 700 land miles $/ 1,100$ kilometres $(\mathrm{km})$. The comparable distance for on-shore pipelines is around 2,200 land miles/3,500 km (Figure 1).

\footnotetext{
* Corresponding author. Email address: hamednikhalat@googlemail.com (H. Nikhalat-Jahromi).
} 


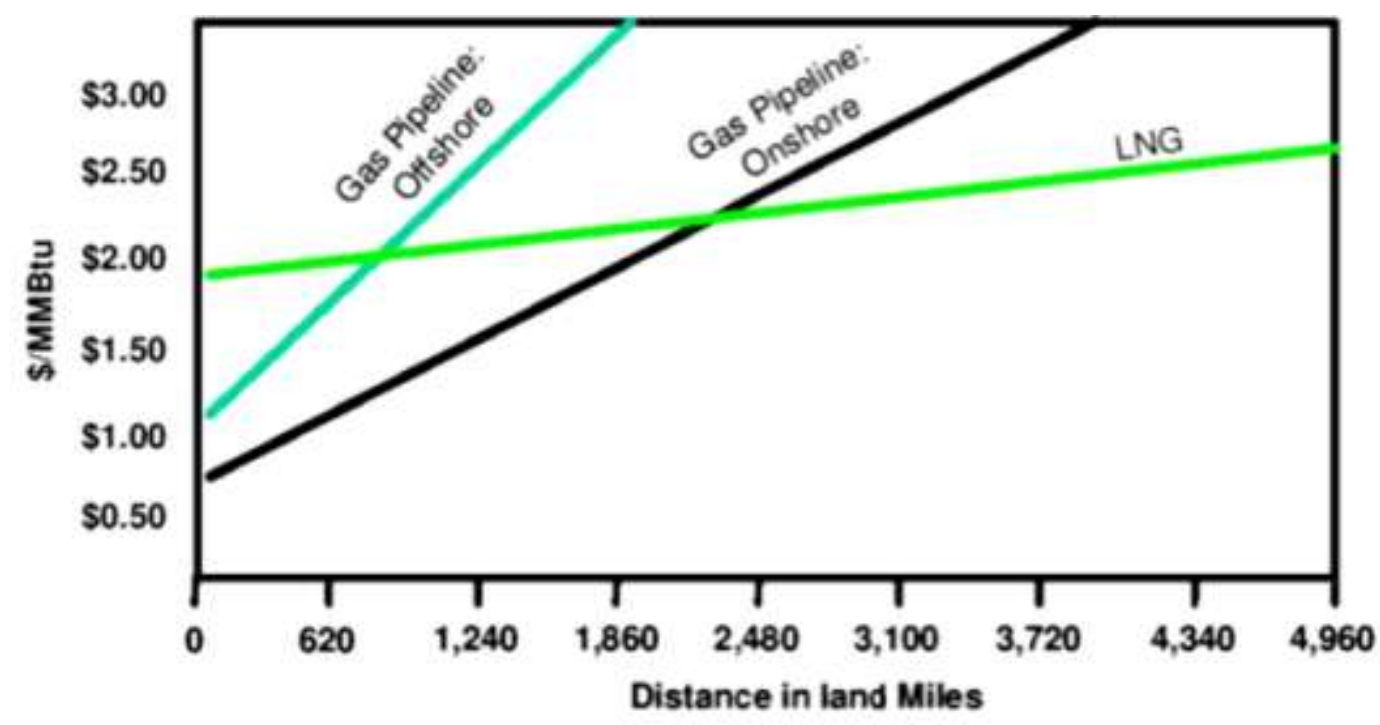

Figure 1 - Comparison of total costs for transferring gas via pipeline and as LNG (source: Michot Foss, 2007)

LNG supplied about 10\% of world gas demand in 2010 and its relative importance is increasing as internationally demand for it grows faster than demand for pipeline gas (Hawk et al., 2013; Kumar et al., 2011). It is possible that due to the maturity of oil fields globally, LNG is going to be one of the main future substitutes for oil, since like oil it can be dispatched to any destination in a tanker provided that the local infrastructure is available. International trade in LNG has grown almost 10 fold from about 25 million tonnes (MT) in 1980 to around 240 MT in 2011 (Figure 2). It is predicted that demand for LNG will grow at about $4 \%$ per year for the next 20 years (Pirrong, 2014).

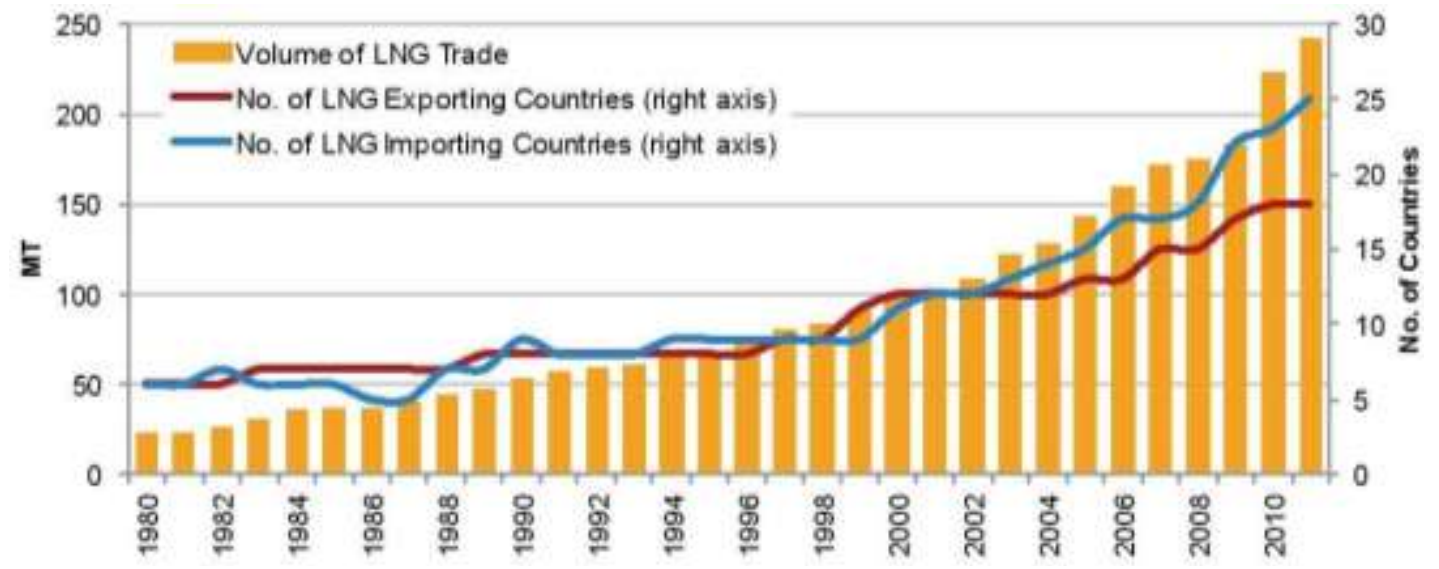

Figure 2 - LNG trade volumes (MT), 1980-2011 (source: IGU, 2012)

This paper provides a comprehensive and up to date analysis of global LNG trade. It analyses and assesses in detail the two methods by which it is sold and bought internationally, namely Long Term Contracts (LTCS) and spot deals.

Whilst earlier work considers the LTC trade (for example; Weems and Hwang, 2013; Roberts, 2011; and Greenwald, 2006), the effects of gas market liberalization (for example; Jensen and Dickel, 2009; and Dickel et al., 2007) or the spot sale of LNG (Zhuravleva, 2009; and Jensen, 2004) there does not appear to be a unified treatment of the LNG market taking account of all these factors. This paper attempts to do so by considering the growing market, taking account of the effects of liberalization and the alternative forms of contract together with project finance factors in a unified manner. 
In the next section, the international trade in LNG is described. This is followed by an analysis of the structure of the traditional LNG trade through LTCs. Later, the gas market liberalization and its consequences for LTCs are considered, followed by a discussion on LNG spot sales. Next, a brief analysis of LNG pricing, up to the point of the sudden drop in oil prices in late 2014 and early 2015, together with some predictions for the future are presented. Finally, the last section outlines the conclusions and suggests some topics for further research.

\section{LNG TRADE FLOWS}

In 2012 there were 17 LNG exporters in the world; see Table 1 for the trade flows of LNG in that year. In addition, six countries namely the US, Brazil, Spain, Portugal, France and Mexico reexported LNG previously imported from another country (GIIGNL, 2013).

The LNG trade saw 25 importers in 2012. Table 1 shows that Qatar supplies more than $30 \%$ of the world's LNG; this country is followed by Malaysia, Australia, Nigeria and Indonesia in terms of market share. These six countries combined exported more than $65 \%$ of the world LNG in 2012. Figure 3 shows the \% share of exporters in global LNG supply in 2012; total LNG exports in this year were around $236 \mathrm{MT}$. 
Table 1 - LNG trade volumes among countries (MT), 2012 (source: GIIGNL, 2013)

\begin{tabular}{|c|c|c|c|c|c|c|c|c|c|c|c|c|c|c|c|c|c|c|c|c|}
\hline & \multicolumn{19}{|c|}{ Exporters } & \multirow{2}{*}{ 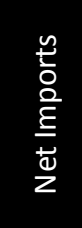 } \\
\hline & $\begin{array}{l}\frac{\pi}{2} \\
\frac{\pi}{d} \\
\frac{60}{\alpha}\end{array}$ & 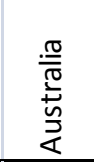 & $\begin{array}{l}\bar{\Phi} \\
\stackrel{\bar{\nu}}{\supset} \\
\stackrel{0}{0} \\
\end{array}$ & 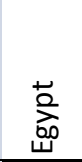 & 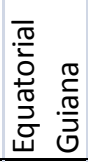 & 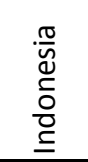 & $\begin{array}{l}\frac{\pi}{2} \\
\frac{\pi}{\sqrt{0}} \\
\sum \\
\sum\end{array}$ & $\begin{array}{l}\frac{\pi}{2} \\
\frac{0}{2} \\
\frac{.00}{2}\end{array}$ & $\begin{array}{l}\text { ते } \\
3 \\
3 \\
2\end{array}$ & 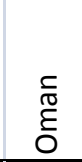 & $\frac{2}{2}$ & $\begin{array}{l}\frac{1}{\pi} \\
\stackrel{0}{0} \\
0\end{array}$ & $\begin{array}{l}\frac{\pi}{N} \\
\stackrel{\underline{n}}{\not{x}} \\
\end{array}$ & 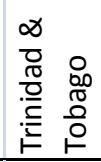 & 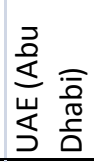 & 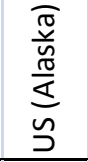 & 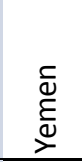 & 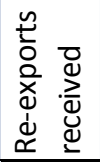 & 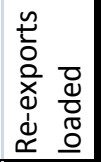 & \\
\hline Argentina & - & - & - & 0.06 & - & - & - & - & 0.18 & - & - & 0.07 & - & 2.32 & - & - & - & 0.74 & - & 3.37 \\
\hline Belgium & - & - & - & - & - & - & - & - & - & - & - & 3.00 & - & - & - & - & - & - & (1.17) & 1.83 \\
\hline Brazil & - & - & - & - & - & - & - & 0.32 & 0.13 & - & - & 1.00 & - & 0.97 & - & - & - & 0.58 & $(0.29)$ & 2.71 \\
\hline Canada & - & - & - & - & - & - & - & - & - & - & - & 0.70 & - & 0.61 & - & - & - & - & - & 1.31 \\
\hline Chile & - & - & - & 0.17 & 0.25 & - & - & - & 0.05 & - & - & - & - & 2.05 & - & - & 0.24 & - & - & 2.76 \\
\hline China & 0.06 & 3.72 & - & 0.31 & - & 2.35 & 1.92 & 0.31 & - & 0.13 & - & 4.90 & 0.38 & 0.17 & - & - & 0.40 & - & - & 14.65 \\
\hline Dominican Republic & - & - & - & - & - & - & - & - & - & - & - & 0.18 & - & 0.74 & - & - & - & - & - & 0.92 \\
\hline France & 3.16 & - & - & 0.60 & - & - & - & 2.11 & 0.19 & - & - & 1.28 & - & - & - & - & - & - & $(0.16)$ & 7.18 \\
\hline Greece & 0.62 & - & - & 0.06 & - & - & - & 0.02 & - & - & - & - & - & - & - & - & - & 0.07 & - & 0.77 \\
\hline India & 0.44 & - & - & 0.52 & - & - & - & 1.34 & 0.06 & - & - & 10.28 & - & - & - & - & 0.38 & 0.24 & - & 13.26 \\
\hline Indonesia & - & - & - & - & - & 0.72 & - & - & - & - & - & - & - & - & - & - & - & - & - & - \\
\hline Italy & 0.70 & - & - & 0.10 & - & - & - & - & 0.06 & - & - & 4.20 & - & - & - & - & - & 0.09 & - & 5.15 \\
\hline Japan & 0.16 & 16.00 & 5.97 & 1.03 & 2.81 & 6.07 & 14.94 & 4.72 & 0.36 & 3.97 & 0.77 & 15.73 & 8.39 & 0.28 & 5.63 & 0.17 & 0.30 & 0.78 & - & 88.08 \\
\hline Kuwait & - & 0.06 & - & 0.12 & - & - & - & 0.57 & 0.13 & - & - & 0.94 & - & 0.17 & - & - & - & - & - & 1.99 \\
\hline$=$ Mexico & - & - & - & - & - & 0.25 & - & 0.75 & - & - & 0.90 & 1.29 & - & 0.11 & - & - & 0.23 & - & - & 3.53 \\
\hline Netherlands & 0.03 & - & - & - & - & - & - & 0.05 & 0.42 & - & - & - & - & 0.06 & - & - & - & - & - & 0.56 \\
\hline Portugal & - & - & - & 0.06 & - & - & - & 1.28 & - & - & - & 0.12 & - & 0.06 & - & - & - & 0.06 & $(0.06)$ & 1.52 \\
\hline Puerto Rico & - & - & - & - & - & - & - & 0.05 & 0.06 & - & - & - & - & 0.86 & - & - & - & - & - & 0.97 \\
\hline Spain & 2.76 & - & - & 0.47 & - & - & - & 3.95 & 1.29 & - & 1.88 & 3.10 & - & 1.80 & - & - & - & 0.48 & $(1.27)$ & 14.46 \\
\hline South Korea & 0.05 & 0.78 & 0.85 & 0.60 & 0.37 & 7.71 & 4.08 & 1.75 & 0.06 & 4.05 & - & 10.81 & 2.10 & 0.89 & - & - & 2.55 & 0.11 & - & 36.76 \\
\hline Taiwan & 0.06 & 0.32 & - & 0.18 & 0.19 & 1.87 & 2.77 & 1.16 & 0.06 & - & - & 5.95 & - & 0.06 & - & - & - & 0.06 & - & 12.68 \\
\hline Thailand & - & - & - & - & - & - & - & 0.07 & - & - & 0.31 & 0.19 & - & 0.05 & - & - & 0.40 & - & - & 1.02 \\
\hline Turkey & 3.08 & - & - & 0.36 & - & - & - & 1.03 & 0.12 & - & - & 0.88 & - & - & - & - & - & 0.16 & - & 5.63 \\
\hline UAE (Duabi) & - & - & - & - & - & - & - & - & - & - & - & 0.95 & - & 0.06 & 0.04 & - & - & - & - & 1.01 \\
\hline UK & 0.08 & - & - & 0.06 & - & - & - & 0.11 & - & - & - & 10.13 & - & - & - & - & - & - & - & 10.38 \\
\hline US & - & - & - & 0.06 & - & - & - & - & 0.13 & - & - & 0.69 & - & 2.24 & - & - & 0.40 & - & $(0.42)$ & 3.10 \\
\hline Exports & 11.20 & 20.88 & 6.82 & 4.76 & 3.62 & 18.25 & 23.71 & 19.59 & 3.30 & 8.15 & 3.86 & 76.39 & 10.87 & 13.50 & 5.63 & 0.17 & 4.90 & 3.37 & (3.37) & 235.60 \\
\hline
\end{tabular}

* Indonesia had a domestic LNG trade in 2012; this shall not be considered as a global trade. 


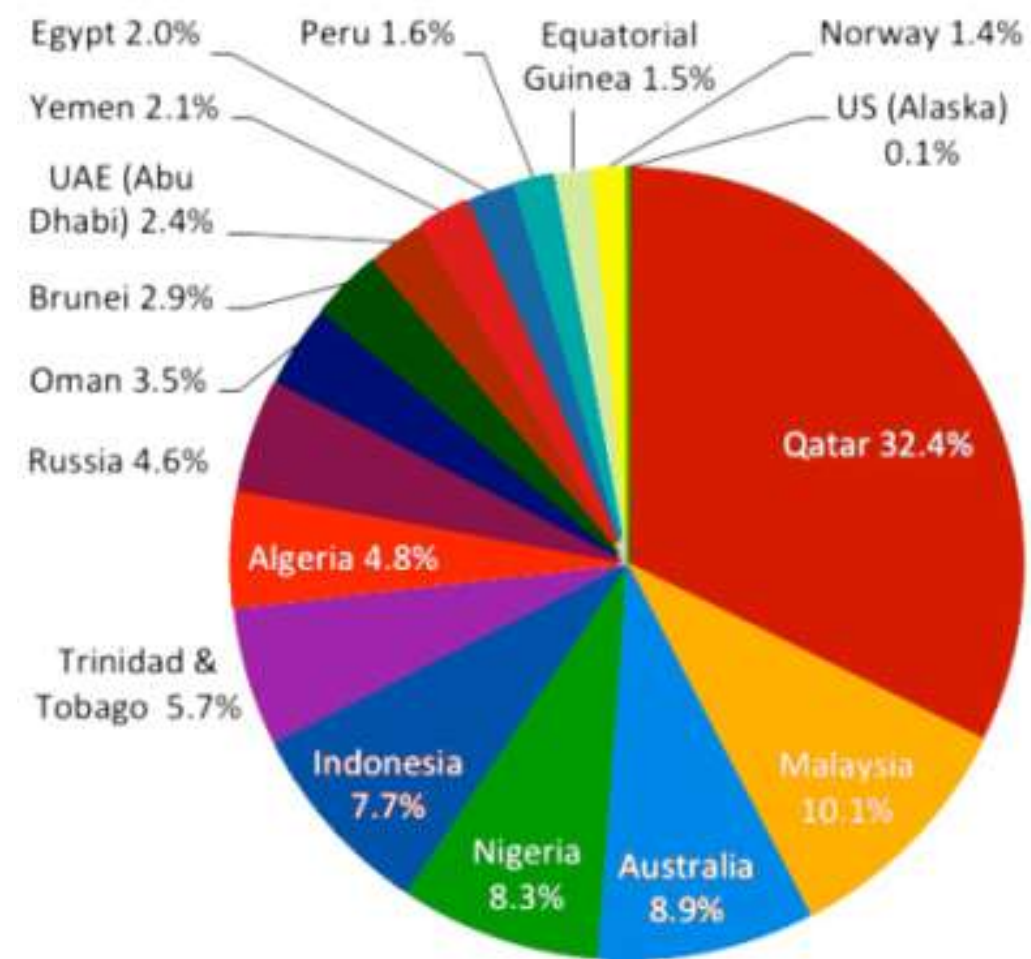

Figure 3 - \% share of LNG exports in global LNG supply by country, 2012

In addition to the remarkable increase in Qatar's LNG supply in the last decade (Drewry, 2010), it is important to note the increasing number of exporters. Figure 4 shows how each country's $\%$ share of LNG exports in global LNG supply has changed as new players have entered the market.

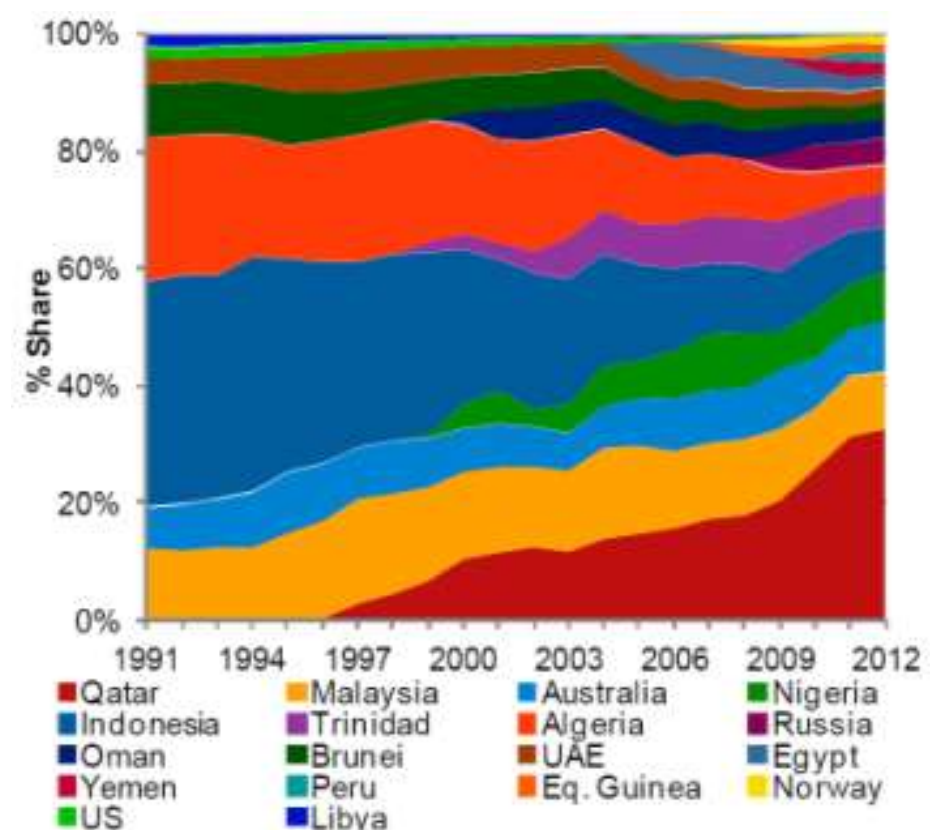

Figure 4 - \% share of LNG exports in global LNG supply by country, 1991-2012 (source: IGU, 2013)

Regionally, Middle Eastern and North African exporters (currently Algeria, Egypt, Oman, Qatar, UAE\Abu-Dhabi and Yemen) left behind Asia-Pacific exporters (Australia, Brunei, Indonesia and Malaysia) in total volumes supplied in 2006 and have continued to put out more volumes since then (Figure 5). 


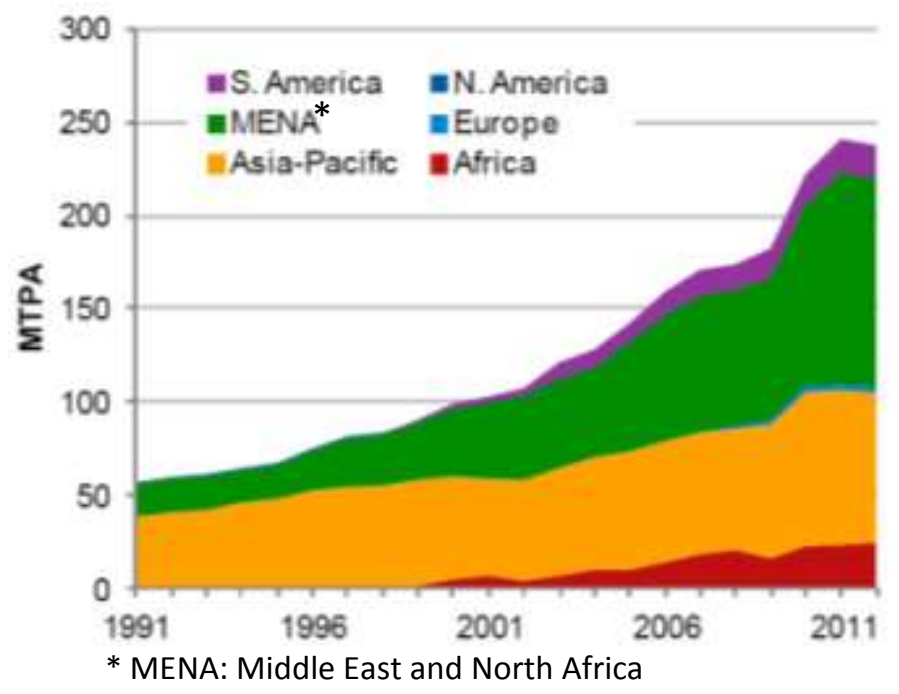

Figure 5 - LNG exports by region in million tonnes per annum (MTPA), 1991-2012 (source: IGU, 2013)

This trend is likely to change in the next decade with an increase in the Asia-Pacific share, as projections for growth in the Middle East and North Africa are limited, while in Asia-Pacific new Australian projects are coming on-stream (Drewry, 2010). Middle East and North Africa face several problems which make development in this region difficult. IGU (2012) has said "these include rising domestic demand, [lack of] regulatory or energy policy clarity, [absence of] economic and political stability, sanctions [in case of Iran], and reserves which are more difficult to recover." These two regions are likely to remain the dominant LNG supply sources for the foreseeable future.

On the import side, Japan and South Korea are by far the biggest LNG importers in the world, such that in 2012 they imported about 125 MT of LNG that is more than $50 \%$ of the world's LNG supply. Japan has been the backbone of LNG trade traditionally, "this country between 1977 and 2001 accounted for over half of global imports (reaching a peak of $74.5 \%$ in 1986) (Drewry, 2010)." Figure 6 shows the \% share of LNG importers from the total LNG imported globally in 2012.

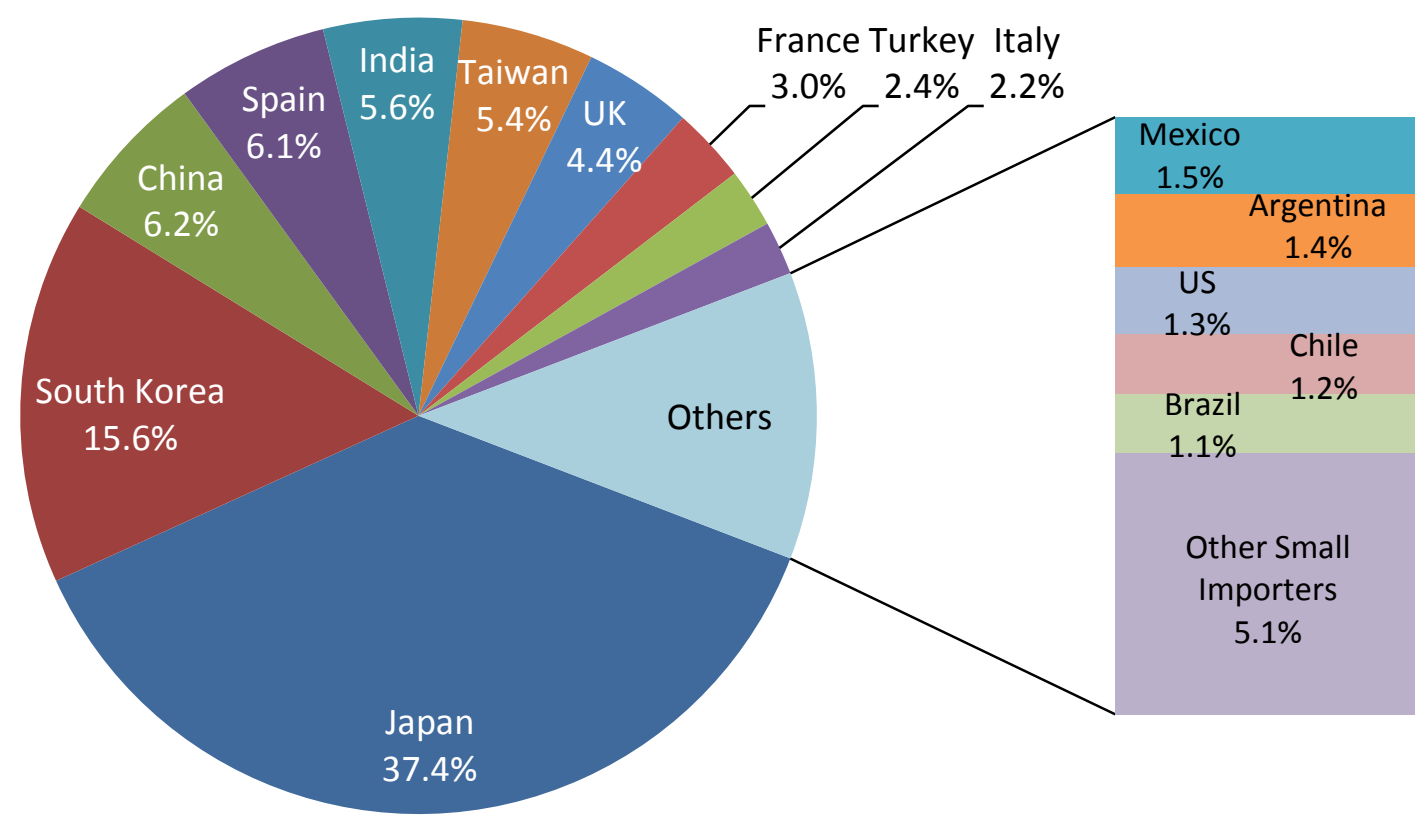

Figure 6 - \% share of LNG imports by country, 2012

Of the 25 importers in above figure, 11 have commenced importing within the last decade, including: Argentina, Brazil, Canada, Chile, China, Kuwait, Mexico, the Netherlands, Thailand, UAE 
(Dubai) and the UK (IGU, 2012). It is interesting to see that three of these countries are located in South America and two in the Middle East, the regions which were not previously importers of LNG and were not expected to be LNG consumers. Indonesia also consumed some LNG in 2012, the volumes regasified in this country were sourced from domestic producers, but it is predicted that Indonesia will be a net importer by the end of the decade (IGU, 2013). Given the numbers provided in Table 1, the trade flows of LNG regionally is as outlined in Table 2.

Table 2 - LNG trade volumes among regions (MT), 2012

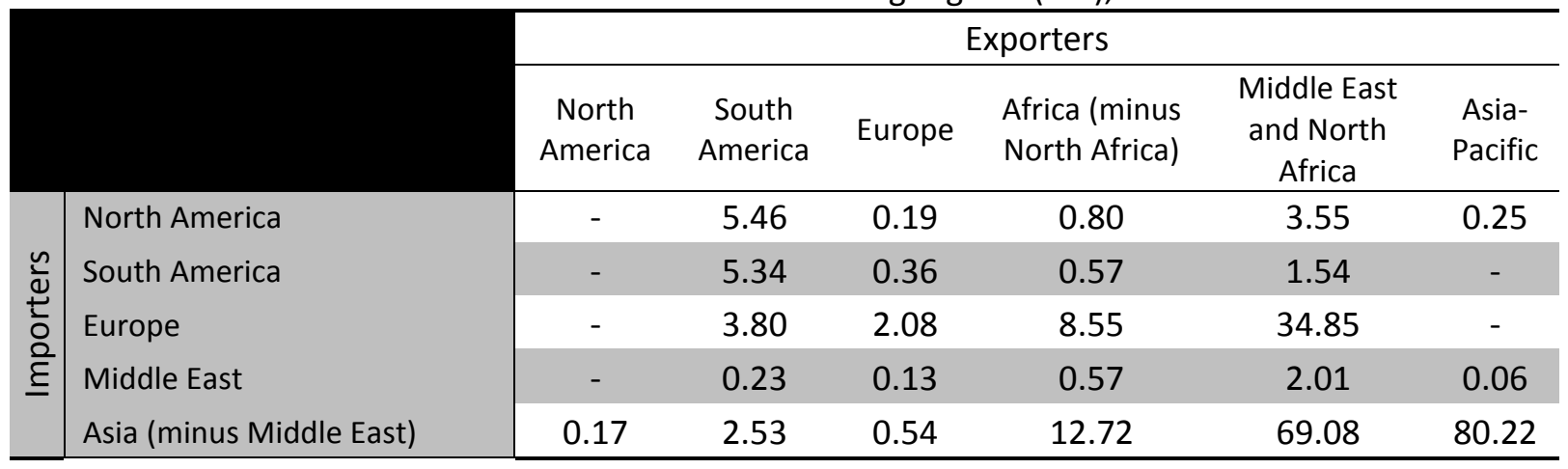

Looking at the table, three major trade flows are identified: from the Middle East and North Africa to Europe (about $35 \mathrm{MT}$ ), from the Middle East and North Africa to Asia (about $69 \mathrm{MT}$ ) and finally from Asia-Pacific to Asia (about $80 \mathrm{MT}$ ). Middle East and North Africa is the swing supplier between Europe and Asia due to its geographical location and significant LNG export capacity (Holz et al., 2013). These numbers imply that currently Europe (including the UK, Spain, France, Italy, Turkey, Belgium, Portugal, Greece and the Netherlands) and Asia (including Japan, South Korea, China, India, Taiwan and Thailand) are the main LNG consumption regions in the world. These two regions are to stay the main importers of LNG over the next decade, while Asia will lead with increasing imports in Japan, South Korea and Taiwan, and the emergence of China and India (Total, 2011). Figure 7 shows LNG imports in various regions between 2005 and 2011, and forecasts it to 2015.

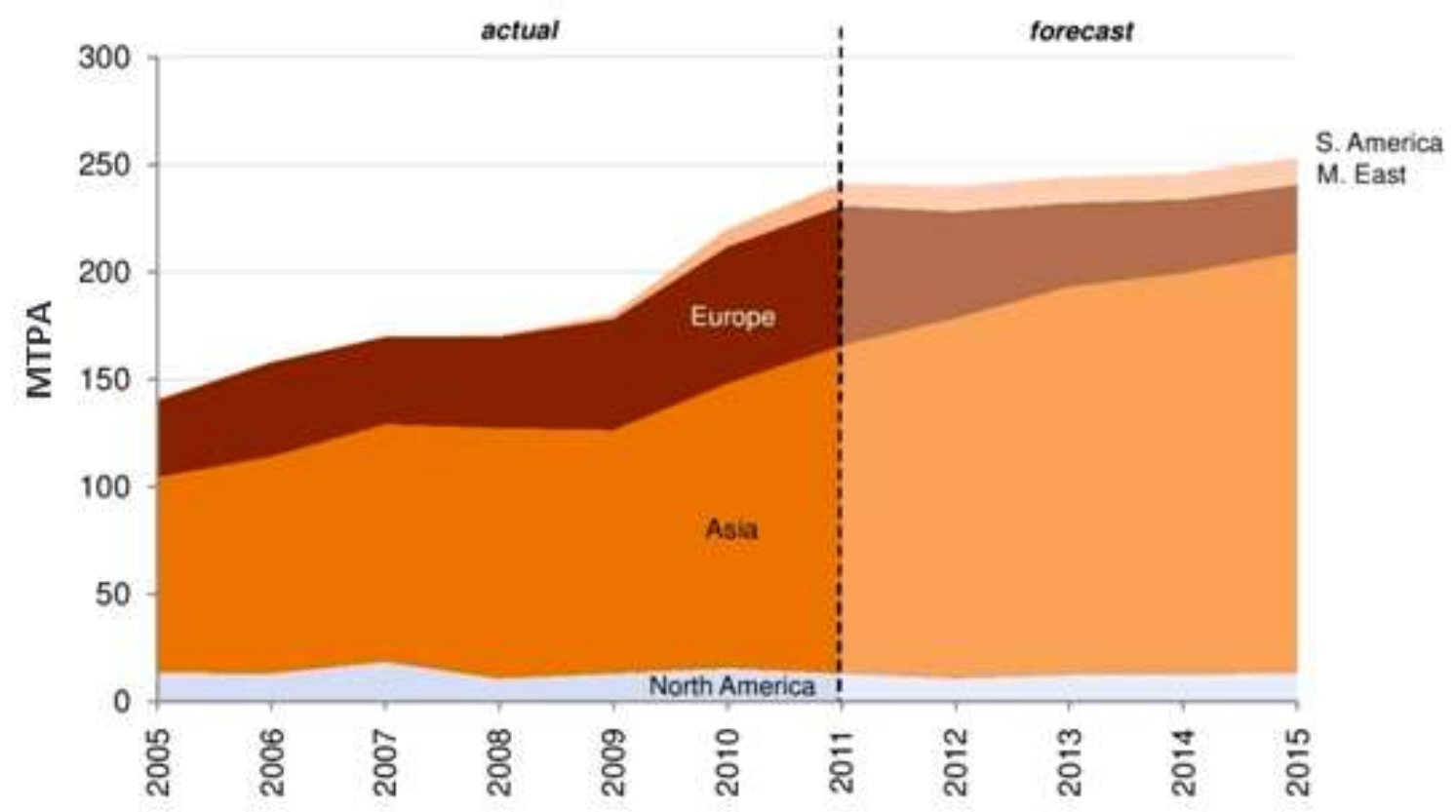

Figure 7 - LNG imports by region (MTPA), 2005-2015 (source: BG Group, 2013) 


\section{THE TRADITIONAL LNG TRADE}

The LNG trade has been based since its expansion in the 1960s on LTCs (Hartley, 2013; Pirrong, 2014), with the duration of the contracts traditionally being 20 to 25 years (Maxwell, 2007). Each contract has two sides, a producer that is also known as seller, and a buyer who is also known as customer.

In such an arrangement, after making sure sufficient supplies of gas are available to make development of a LNG supply enterprise commercially viable; a group of companies and institutions is assembled to finance and develop the enterprise; this group usually includes commercial banks, multilateral lenders, export credit agencies, the national oil company (NOC) of the host country and international oil companies (IOCs) (Taylor-DeJongh, 2004). The IOCs and NOCs are usually equity investors that are the sponsors/owners of the enterprise, while the commercial banks, multilateral lenders and export credit agencies are loan providers (Jensen and Dickel, 2009).

The sponsors may develop the LNG supply enterprise in the form of a project company or through a non-incorporated joint venture company. Under the first arrangement, the project company purchases gas from the upstream gas suppliers, markets the LNG, enters into LTCs with the buyers (there is often more than one LNG purchaser from a LNG supply enterprise) as the producer, and passes the revenues generated to the sponsors/shareholders as dividends. The project company structure paves the way for non-recourse enterprise financing. Under the project company structure, sponsors may also raise additional capital by issuing bonds for the enterprise (Sato, 2000).

In the alternative non-incorporated joint venture structure, each partner owns a proportion of the LNG supply enterprise, delivers a fraction of the feed gas to the enterprise (proportionate to its enterprise ownership), enters into a LTC with each buyer from the enterprise as the producer, and is entitled to a fraction of revenues generated yet again in proportion to its enterprise ownership. In a non-incorporated joint venture structure, partners often enter into a joint marketing agreement through which one of the sponsors sells the LNG produced on a commingled basis (Weems and Hwang, 2013).

The non-incorporated joint venture structure is used in countries where it is recognized as a legal construct and there is legislative support for it, particularly in enterprises where the host country does not want to take an active role in the business and just imposes royalty and tax on it or enterprises where the sponsors are not concerned with significant liabilities that may arise from the enterprise developed hence do not seek protection by establishing a separate entity (Reuter, 2003; Weems and Sullivan, 2005).

In both the project company and the non-incorporated joint venture structures, one of the sponsors usually runs the enterprise operations on behalf of the others. The project company structure has been used for LNG supply enterprises in Nigeria, Trinidad and Tobago, Angola, Australia, Peru, Malaysia, Equatorial Guinea, Qatar, Russia, Yemen and Oman. Supply enterprises in Australia, Papua New Guinea, Norway, Indonesia and Alaska have adopted the non-incorporated joint venture structure (Weems and Hwang, 2013).

In addition to the methods mentioned above to develop a LNG supply enterprise, there is a third way of making LNG available to the market, named the tolling company arrangement. Here the tolling company neither owns the gas it receives nor the LNG it produces, but rather merely provides a service to those that supply the company with gas for a negotiated fee. Each gas supplier lifts its LNG and sells it as the producer to its buyers. The gas suppliers commit to the LNG generation capacity of the tolling company. The tolling company arrangement has been used occasionally in Indonesia, Egypt and Trinidad and Tobago (Flower, 2013; Weems and Sullivan, 2005). This 
arrangement has not been as common as the two structures introduced above, and is not discussed in detail in this paper.

The buyer is the party on the other side of the LTC. These companies have traditionally been regulated utilities or governmental companies with monopoly markets within a developed country. They, too, usually raise money from commercial banks, multilateral lenders, etc. in the form of loans to develop the infrastructure for receiving LNG in their own side (Maxwell, 2007).

LNG is delivered through a supply chain that encompasses four phases (Figure 8): extraction in which natural gas is extorted from the gas field; liquefaction where contaminants of natural gas are removed and it is liquefied; shipping which is carried out by double hulled tankers; finally, regasification. In this final step, the liquid gas (LNG) is received and regasified in two stages: the first is a warming process to convert it to gas; next its pressure is adjusted to the value used in the trunk gas supply grid.

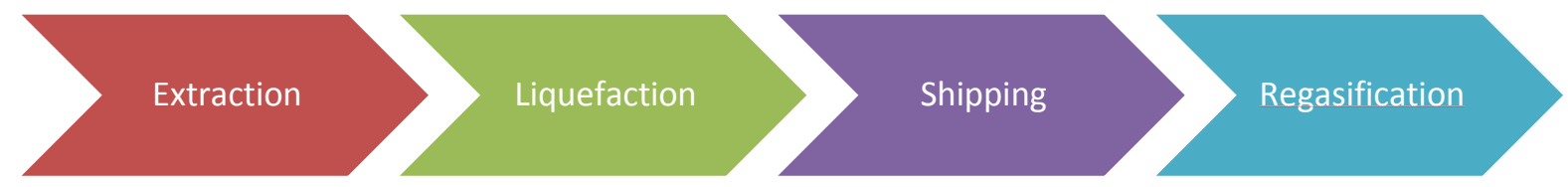

Figure 8 - LNG supply chain

In the longest established form of LNG trade, in developing a LNG project (made up of the above mentioned four phases) the producers are responsible as a minimum for establishing the upstream liquefaction plant facilities and the buyers provide the downstream facilities. These are the regasification terminals, with each buyer usually building its own terminal (Lee, 2005). Tankers for shipping are sometimes dedicated to a specific LTC and may be owned by the buyers, the producers or a third party. Carriage is the responsibility of the producers in cost-insurance-freight (CIF) and delivered ex-ship (DES) contracts and of the buyers in free-on-board (FOB) contracts.

The core of a LNG project is the LTC, a sale and purchase agreement that establishes the rights and obligations of the parties involved (Adegun, 2006). This agreement sets out responsibilities for the main risks, i.e. volume and price risks, between the buyer and the producer. The buyer takes the volume risk while the seller takes the price risk (Enobun, 2008). The most important clauses in LTCs are:

i. Commodity quality and quantity: the quality and quantity of LNG to be delivered is written into the contract. This clause also states what happens if one of these specifications is not fulfilled (Osiliko, 2005).

ii. The destination clause: the LTC seeks to prohibit a buyer from selling, or procuring the sale of, the LNG which is to be delivered to the principally identified regasification terminal/ destination/market, to any alternative market. Imposing the destination clause on CIF/DES contracts is easy and commonplace as the producer manages the transport of LNG. In FOB contracts, where the buyer has the control of the product on-board the tankers, enforcing this clause is much more difficult. It should be noted that destination clauses are effectively territorial restrictions, intended to preserve market separation for the LNG producers (Roberts, 2011). Buyers are interested in FOB contracts since it facilitates trade of surplus LNG, i.e. what they do not use themselves, with other importers. Whereas producers seeking to protect their business interests may press for CIF/DES contracts (Chandra, 2006).

iii. Take-or-pay provision: take-or-pay is a clause in the LTC that "entitles a buyer to take a minimum quantity of gas each year and obliges the buyer to pay for that minimum quantity 
whether or not this is actually taken (Davey, 1997)." Usually more than 90\% of the annual production of a liquefaction plant is sold under this clause and the remainder sold on spot (Jensen, 2004).

iv. Price: price is an important factor in securing the revenue in a LNG project. LTCs do not usually have a fixed price over the life of the contract, but rather they conventionally have a formula which relates the price of the cargos to competitive energy sources at the time of delivery to the destination (Mukherjee and Panandiker, 2014); with sometimes a minimum price to protect the producer from a complete collapse in prices and a maximum price to protect the buyer from exceedingly high prices (Abdulkarim, 2008).

The philosophy underlying the use of LTCs in projects like LNG with heavy capital expenditures in upstream (Table 3 ) is that the form of contract should reassure the LNG supply enterprise's lenders that their investment is secure. These contracts include a take-or-pay provision that assures the lenders there is a minimum steady income for the LNG supply enterprise by which it can cover its debt service and pay the operating costs in order to keep the enterprise running and generate revenue (Greenwald, 2006). In fact, during the negotiations between the LNG supply enterprise and their lenders, the lenders will ask for copies of the proposed or existing LTCs and transport agreements as the proof of having sufficient vessels for the carriage of LNG before giving a go ahead to the project (Abdulkarim, 2008). Note that in LNG supply enterprises with the project company structure, the project company will negotiate directly with the lenders, while for the enterprises with the non-incorporated joint venture structure, the partners will usually have to make an arrangement such as an adjoining offshore sales and financing vehicle to seek loan finance (Weems and Hwang, 2013).

Table 3 - Capital expenditures on a 5 MTPA LNG supply chain (source: Mukherjee and Panandiker, 2014)

\begin{tabular}{|c|c|}
\hline Activity & Capital expenditure in billion dollars \\
\hline Extraction & $2-6$ \\
\hline Liquefaction plant & $6-10$ \\
\hline Shipping & $1-2.5$ \\
\hline Regasification terminal & $1-1.5$ \\
\hline Total & $10-20$ \\
\hline
\end{tabular}

The upstream lenders, after checking LTCs, evaluate the credit worthiness of the buyers too. This is because, even with a take-or-pay provision, if the buyer cannot fulfil its obligations the LNG supply enterprise will face cash-flow problems and will not be able to do its debt service (Radetzki, 1999). LTCs are important for the buyers too. Using such a contract, a buyer can convince its lenders that there is a solid supply of gas by selling which it can repay its loans.

Lenders in LNG projects are not only concerned with commercial risk, but will also consider other things such as the political risks associated with the project, before making a decision on the finance request (Razavi, 1996).

\section{GAS MARKET LIBERALIZATION AND ITS IMPLICATION FOR LNG LONG-TERM CONTRACTS}

One of the goals pursued by many governments as part of their energy policy agendas is opening their gas markets, which have in the past been characterised by monopolies, through liberalization. The objective of liberalization is the introduction of competition to the market (Omorhirhi, 2006). Liberalization of the markets has provided third-party-access by regulation to the gas transmission 
and distribution facilities in the US and Europe; in the LNG sector, this will be the regasification terminals (King \& Spalding, 2004). With third-party-access, infrastructure owners must grant access to third-parties with regulated tariffs on transparent and non-discriminatory terms when capacity is available; the unbundling of the infrastructure might be imposed too (Encke, 2012).

Enobun (2008) has said that "the open market policy crept into the LNG market to forestall the monopolistic power of the LNG buyers" in the US and Europe. In reality, there have been three main and distinguishable regions which are markets for LNG: Asia, i.e. Japan, South Korea and Taiwan, and more recently India and China; Europe including the Continent and the UK; and North America, essentially the US (Dickel et al., 2007). The US and UK are mature liberalized markets while the liberalization process in Continental Europe continues. Asian LNG consumers are still far from having a liberalized gas market (IEA, 2012).

Even under highly liberalized regimes in both the US and Europe, infrastructure owners can seek exemption from mandatory third-party-access on all or part of the capacity, reserve the capacity for themselves (as in for example the South Hook regasification terminal in UK) or sell it on negotiated terms and prices that in many cases are on a long-term basis, for instance in the Grain regasification terminal in the UK. Exemptions have been granted to many new regasification terminals in Europe and the US (King \& Spalding, 2004). Today, in Europe, the national regulatory authorities, for instance the Office for Gas and Electricity Markets (OFGEM) in the UK, given the Directive 2009/73/EC also known as the Third Energy Package Gas Directive (EC, 2009) and its Article 36 can grant the exemption.

In the US, the Federal Energy Regulatory Commission (FERC) can under the Hackberry Decision (2002) grant the relief and to the best knowledge of writers, FERC has not called for any mandatory third-party-access since 2002. These exemptions in the US and Europe aim at encouraging investment for building new and upgraded infrastructure (Dickel et al., 2008). The large numbers of exemptions indicate the tension between ensuring full open access and encouraging heavy private investment in long term infrastructure. For a review of the regasification terminals, their capacity, access arrangements and measures in Europe, see CEER (2013). Jensen and Dickel (2009) provide a perspective on regasification terminal arrangements in the US.

In the US and Europe there has been a movement towards the construction of regasification terminals by transmission companies rather than LNG buyers. These companies sell the capacity to other corporations with marketing activities (this is the case in the Gate regasification terminal in Netherlands). Also, regasification terminals are built by the buyer sponsor in self-contracts (these contracts are discussed later in this section) for accessing the markets (for example the South Hook LNG terminal in UK) (IEA, 2012).

As the result of liberalization and competition in the gas markets, there is a considerable pressure to make LNG contracting more flexible, but producers have shown a great unwillingness to develop a new LNG project without the level of protection provided by a LTC. Thus, the industry is expected to continue to rely on LTCS to support major new investment and this would act as the filter that determines the flow of new projects into the market (Dickel et al., 2007).

In the US and UK which have fully liberalized gas markets, LNG buyers are now smaller and much more sensitive to price competition since their monopoly position has been eliminated. In these markets, they are exposed to increasing volatility in gas prices (Abdulkarim, 2008), and the majority of buyers cannot assume a volume risk without a market-responsive pricing clause (Jensen, 2004). With such an arrangement "since the buyer can so easily resell unwanted volumes in the liquid spot market with limited financial loss ... [its] risk has been significantly reduced. Risk has thus migrated 
upstream ... (Jensen and Dickel, 2009)". The reaction of producers to this has increasingly been towards self-contracting.

In self-contracting, one of the sponsors in the LNG supply enterprise, often an IOC, signs a LTC with the project company (or LTCs with the partners in an enterprise with the non-incorporated joint venture structure) and becomes the buyer. This buyer sponsor is responsible for marketing the product with a very relaxed destination clause which permits easy change of destination (Jensen and Dickel, 2009). Approval for a change in destination is not to be unreasonably withheld by the producers in self-contracts (Flower, 2013).

Many of the IOCs with self-contracts (e.g. BG, BP and Shell) have made LNG portfolios for themselves, combining the supply of LNG from several enterprises and using their tankers to feed into owned or booked regasification capacity in Europe and the US. Such an IOC/portfolio player tries to optimize its profit through commercialising its flexibility (Jensen and Dickel, 2009). The margin in changing the destination in self-contracts is shared with the LNG supply enterprise since there are rent sharing mechanisms in arbitrage (arbitrage is discussed in the next section.)

In the US and the UK, where spot markets dominate the onshore gas trade, self-contracting permits the multinational buyer sponsor to participate in the market, and this type of contract is very important in these countries. Self-contracting allows the buyer sponsor to sell the gas to smaller resellers (e.g. utilities) or directly to consumers in liberalizing/liberalized gas markets (Dickel et al., 2008). See Figure 9 for a comparison of self-contracts and the traditional LTCs. 


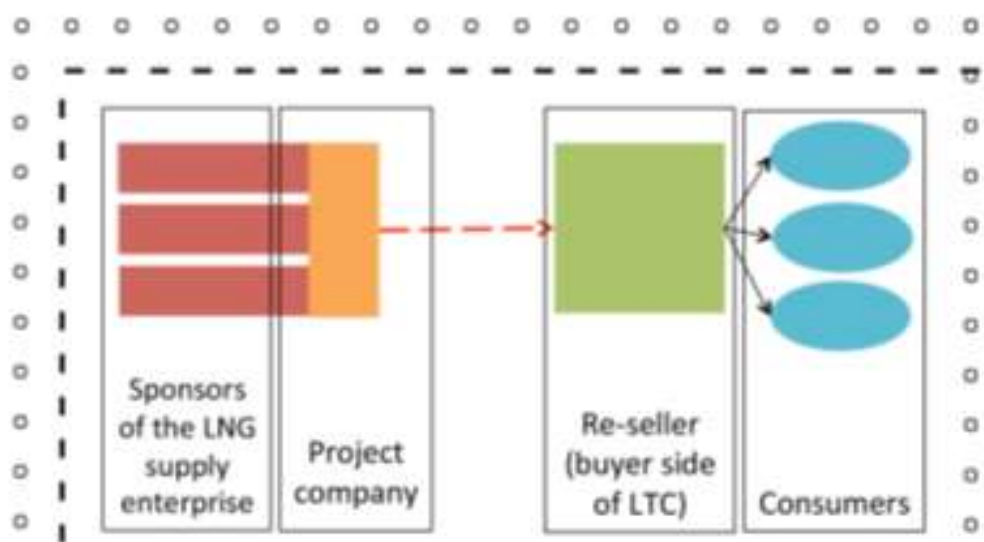

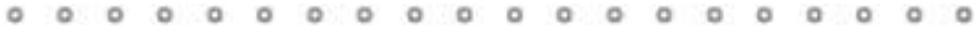
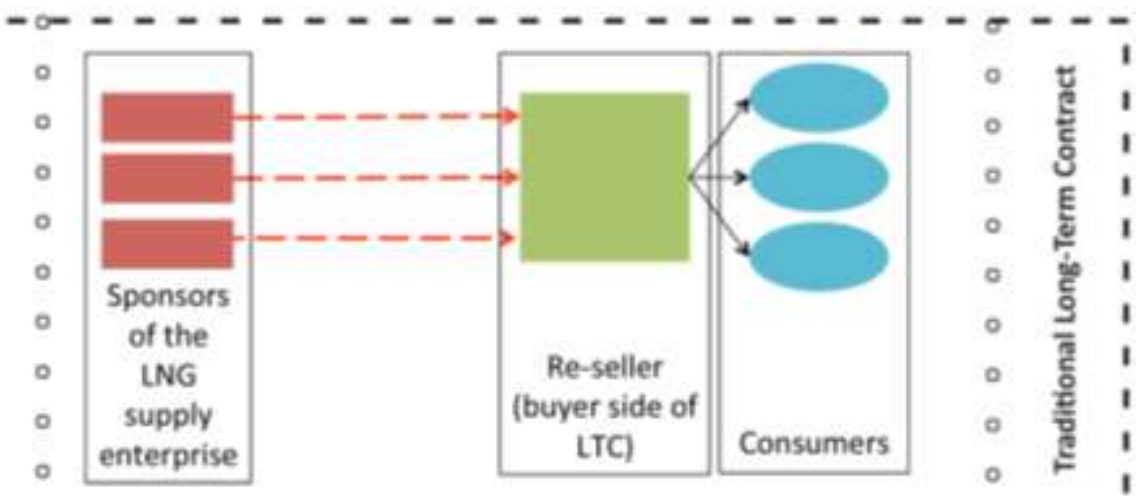

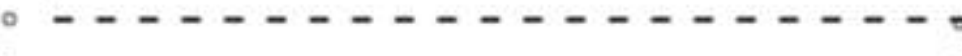
$-c$

$\circ$

i
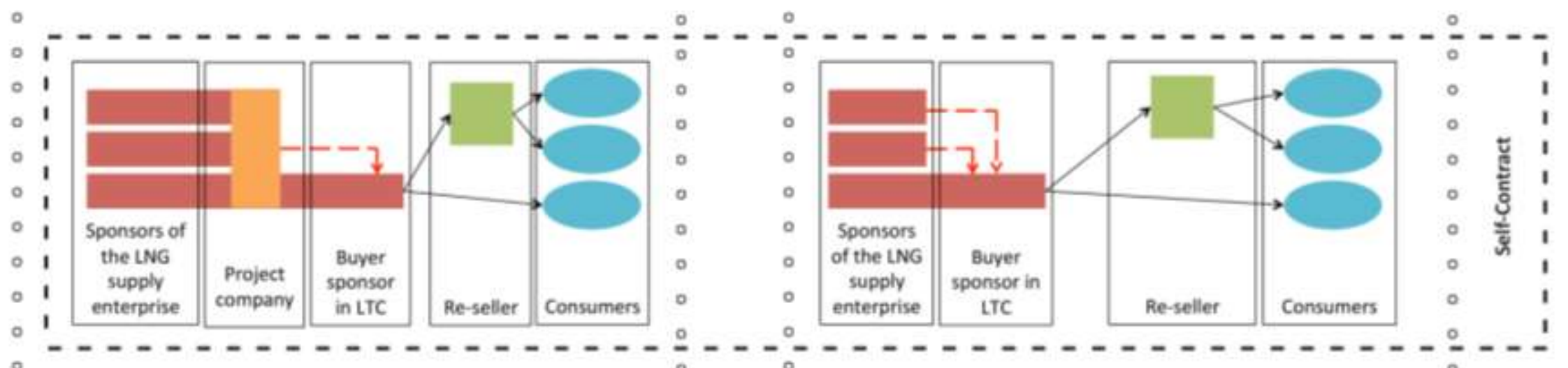

Supply Enterprise with the Project Company Structure

- Supply Enterprise with the Non-incorporated Joint Venture Structure 。

$\circ 000000000000000000$

$\circ 0000000000000000000$ $\underset{\text { Long-Term }}{\longrightarrow \text { Contract }}$

Figure 9 - Comparison of the traditional LTC and the new self-contract 
The traditional LTCs which are not self-contracts remain important in Continental Europe, and are still the dominant type of contract in Asia (Dickel et al., 2007).

Due to the surge of domestic shale gas production, the volume of LNG imports to the US has decreased substantially and cargos since 2008-2009 have been arbitraged to Europe and Asia. As such, some regasification terminals in the US previously used for imports are converted to liquefaction plants and new liquefaction plants are developed for exporting the surplus gas produced indigenously as LNG (Hartley, 2013; Natural Gas \& Electricity, 2014).

As a result of LNG arbitrage from the US and the prospect of future LNG supply growth from this country, new traditional LTCs are shorter than before and are now in the range of 10-20 years (Argus Global LNG, 2011). In 2008 about $18 \%$ of world LNG supply was carried out on self-contracts and about $75 \%$ on traditional LTCs, with the highest penetration of self-contracting being in the Atlantic Basin (Figure 10). It appears that the traditional LTCs are still the main LTC type in place in the LNG sector.

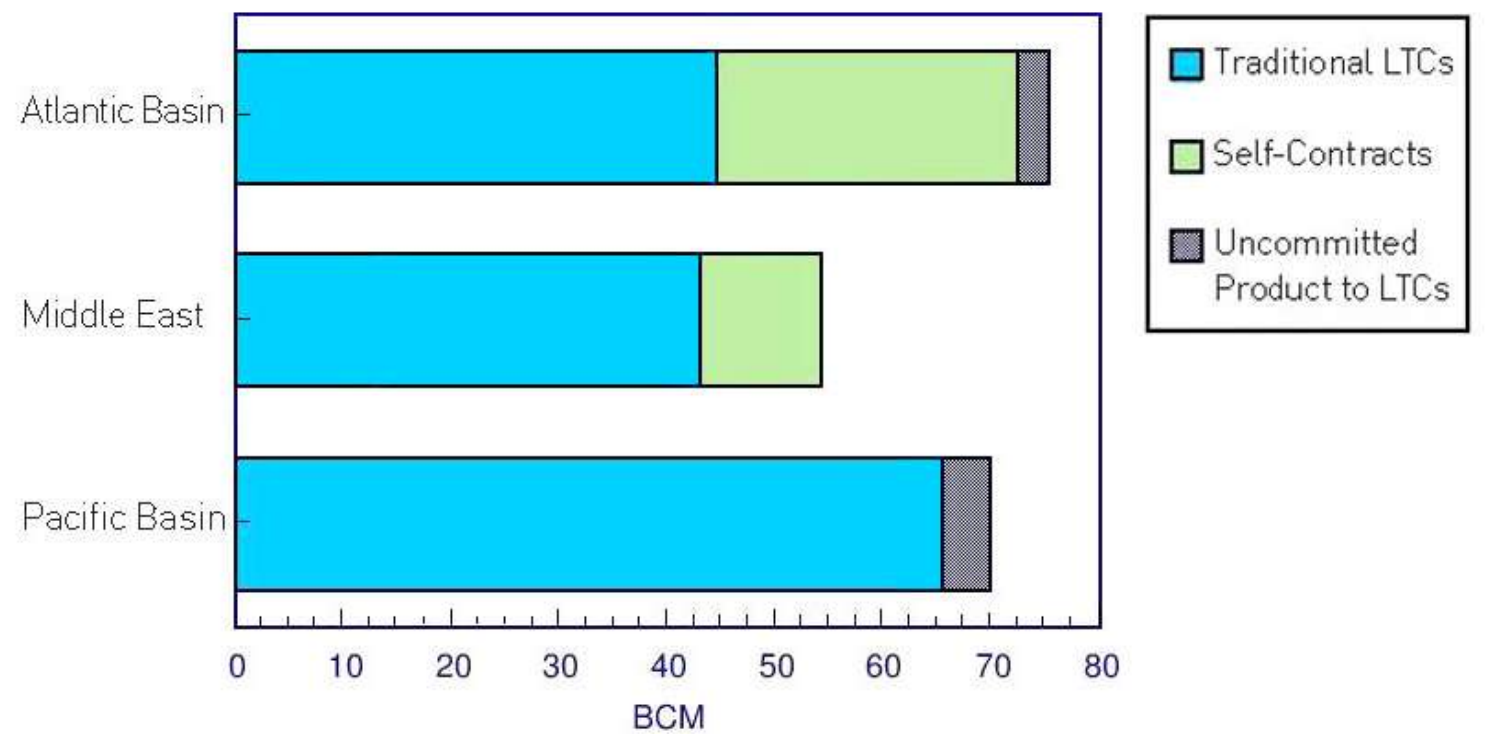

Figure 10 - Regional supply sources of LNG given their LTC commitments (BCM) in 2008 (adapted from: Jensen and Dickel, 2009)

\section{SPOT SALE OF LNG FOR UNCOMMITTED PRODUCT AND IN ARBITRAGE}

Over-the-counter (OTC) spot sales in the LNG sector consist of two groups: genuine single cargo spot sales and short-term sales. In short-term sales, there is a series of LNG cargo sales based on a shortterm contract usually with the duration of less than four years (Jensen, 2004). The main differences between these short-term contracts and LTCs according to Abdulkarim (2008) are:

i. Take-or-pay provision: although it might still exist in the contract, it does not cover the volume risk over the life of the loan provided by the lenders in LNG project development.

ii. Fixed price: the price in this type of contracts might be fixed. There is no point for time dependent prices, especially for very short ones.

The importance of spot sales in the LNG sector has grown over the years. Figure 11 shows the growth of spot sale volumes and its share of the total LNG trade between 2000 and 2012. In 2012, 
the main exporters active in LNG spot supply were Egypt, Equatorial Guainía, Nigeria, Trinidad and Tobago, Indonesia and in particular Qatar; while the main importers were Spain, the UK, Brazil, China, India, Taiwan, Japan and South Korea. More than half of the 59 MT spot LNG trade in 2012 was absorbed in Northeast Asia (GIIGNL, 2013); Japan in the wake of Fukushima nuclear crisis and the resulting need for replacing nuclear power supply was the biggest spot LNG importer in 2012 (IGU, 2013); this country imported 19 MT of spot LNG (GIIGNL, 2013). In general and over time, Northeast Asia has been a primary market for LNG spot cargos (Rogers, 2010).

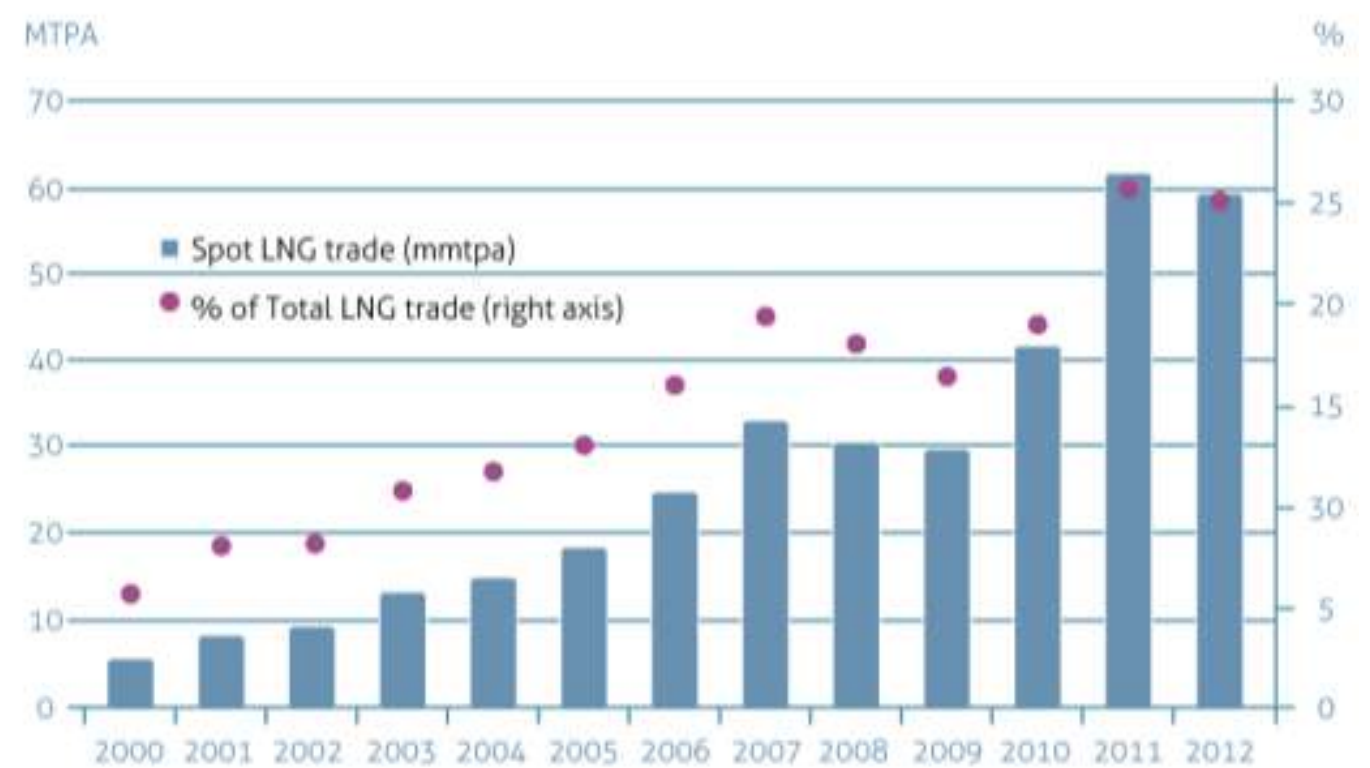

Figure 11 - Volume of spot LNG trade and its share of total LNG trade (MTPA), 2000-2012 (source: GIIGNL, 2013)

There are two main types of spot sale that both involve the LNG producer: the spot sale of uncommitted product (that is the product which is not sold on LTCS), and arbitrage. There are also spot sales that do not involve the producer, perhaps the most significant of which is the re-export sale. Here, the buyer in a traditional LTC receives the LNG in the principally identified regasification terminal in the contract, but as soon as the cargo is discharged to the tanks of the terminal, it belongs to the buyer and the producer does not have any rights over it. The buyer next loads the LNG to a tanker and dispatches it to a market with higher prices (Zhuravleva, 2009). Spot sales that do not involve the producer do not appear to be as important as the aforementioned spot sale types and are not discussed in detail in this paper.

The sources of uncommitted product spot sales include: the surplus capacity of the liquefaction plants over the ramp-up period of the LNG projects (the ramp-up period is the period between the start of LNG production to the time that the long-term buyers develop their business and can take all their contracted product); increases in capacity of older liquefaction plants; production after the initial LTCs expire; and a proportion of each liquefaction plant's output that is uncommitted and dedicated to spot sales (Jensen, 2004). The last is generally small and often less than $10 \%$ of annual production.

Over the past few years it has become an acceptable industry practice for the LNG cargos on LTCs with principally identified destinations to be diverted to other markets with mutual agreement of the producer and the buyer to be sold on spot (Yegorov and Dehnavi, 2012). This practice, termed arbitrage, is facilitated in self-contracts but occurs in traditional LTCs too. 
The drivers for arbitrage are either commercial or operational. An arbitrage with a commercial incentive occurs for the sake of cost minimization or revenue maximization with the purpose of a higher profit. The cargo arbitrage with operational incentives in the LNG sector may take place due to reasons such as regasification terminal outages, overfull storage tanks, unrests, embargos and conflicts. Here, the driver of arbitrage is not a higher profit, but rather that circumstances enforce the diversion of the cargo (Anyanwu, 2010). According to Zhuravleva (2009), three distinct varieties of arbitrage can be defined:

i. The producer as the arbitrageur: in this model of arbitrage, the producer initiates the arbitrage and offers the cargo diversion to the buyer side of the LTC, and shares the margin of arbitrage with him. The buyer may accept the arbitrage subject to replacement of the cargo. A case of this type of arbitrage happened in 2008. In March of that year Oman diverted a cargo to Asia with the cargo being primarily assigned to Spain on a traditional LTC.

ii. The buyer as the arbitrageur: in this form of arbitrage, the buyer decides to divert the cargo to another market and offers the diversion to the producer. The margin is divided between the producer and the buyer. This type of arbitrage often happens in Spain due to the limited storage capacity in this country.

iii. An independent trader as the arbitrageur: an independent trader, such as a bank, buys the cargo or achieves the right to divert the cargo. This trader might need to replace the cargo for the buyer side of LTC. The independent trader would have to share the margin with the producer and the buyer.

\section{LNG PRICING}

The pricing of LNG differs between markets. Prices in Continental Europe, Northeast Asia, India and China in LTCs are linked to rival energies. These prices are the result of negotiations between the buyers and the producers who want to get the highest possible profit for the depletion of their national resources. But in the UK and the US, prices are determined by competition among different suppliers in the liberalized gas market (Dickel et al., 2007). The likelihood of there being a uniform international pricing scheme for LNG is at present remote (Ritz, 2013).

Pricing of LNG in the US and Europe: there are two types of pricing for LTCs in these markets. These are pricing linked to the gas market indicators, namely Henry Hub and the National Balancing Point (NBP), respectively for the US and the UK (Maxwell, 2007), and pricing linked to oil or oil products and coal, depending on the country, for Continental Europe (Mukherjee and Panandiker, 2014). In Continental Europe, due to increasing competition from pipeline gas, the indexation pattern for LNG tends to follow the same structure as on-shore gas and the ongoing gas market liberalization process in the continent is making LNG pricing more competitive (Davoust, 2008).

In reality, the pricing is more complex. As Dickel et al. (2007) report, "while the NBP in the UK represents a single, and theoretical, transaction point, the North American market has many other transaction points, also known as hubs, keyed to Henry Hub by basis differentials. While these [differentials] in theory approximate the costs of transportation between Henry Hub and the alternative hub, they can easily differ significantly depending on market conditions. The contracting that has taken place for the US market appears to be on a netback basis.... They thus feature a reference price, such as Henry Hub, and may include basis differentials if deliveries are made into a market served by one of the other market hubs. Prices may be adjusted monthly ..., or they may be 
adjusted more frequently based on either the daily quotation or on a several day average to dampen volatility."

LNG pricing in Northeast Asia, China and India: the importing of LNG to Japan began as a result of evolution in the electric utility industry in the 1960s. At that time the Japanese electricity industry was based on oil, coal and hydropower, with heavy fuel oil and crude oil accounting for around $40 \%$ of the power generated. In view of the fact that reducing oil imports was a main policy for the Japanese at that time, replacing oil with LNG in generating electricity became an important objective. Therefore, the competitive price target for LNG in Japan became oil (Jensen and Dickel, 2009).

The price formulas in Japanese LTCs primarily were tracking the oil sale prices of the LNG producers, but since 1987 nearly all Japanese contracts follow the Japan Customs-cleared Crude oil price (JCC). Later when Taiwan and South Korea became active in the LNG market, they too adopted the JCC price escalation scheme; this scheme is now common in the entire South and East Asian region (Dickel et al., 2008).

The most common pricing formula in Asia is: price $=\mathrm{A} \times \mathrm{JCC}+\mathrm{B}$. Here $\mathrm{A}$ is a coefficient which links the JCC price in dollars per oil barrel $(\$ / \mathrm{bbl})$ to the LNG price that is in dollars per million British thermal unit ( $\$$ /MMBTU), and $B$ is a constant in $\$ / M M B T U$. The JCC price is published monthly but the LTCs, which follow it with a few months of lag (McHugh, 2015), usually average it over a period to dampen any fluctuation (Fujime, 2002). The volatility in oil prices due to the crises in oil market has encouraged buyers to ask for a cap in pricing LNG in Asia; this means if the oil price goes over a specific value, the LNG price would be set as this cap. On the other hand, producers have asked for a floor to protect themselves against sharp falls in oil prices. The resulting scheme of pricing is called a S-curve (Davoust, 2008). Figure 12 is a S-curve with floor and cap respectively at $15 \$ / \mathrm{bbl}$ and 30 $\$ / \mathrm{bbl}$, and a LNG price formulation of: price $=0.1485 \times \mathrm{JCC}+0.80$.

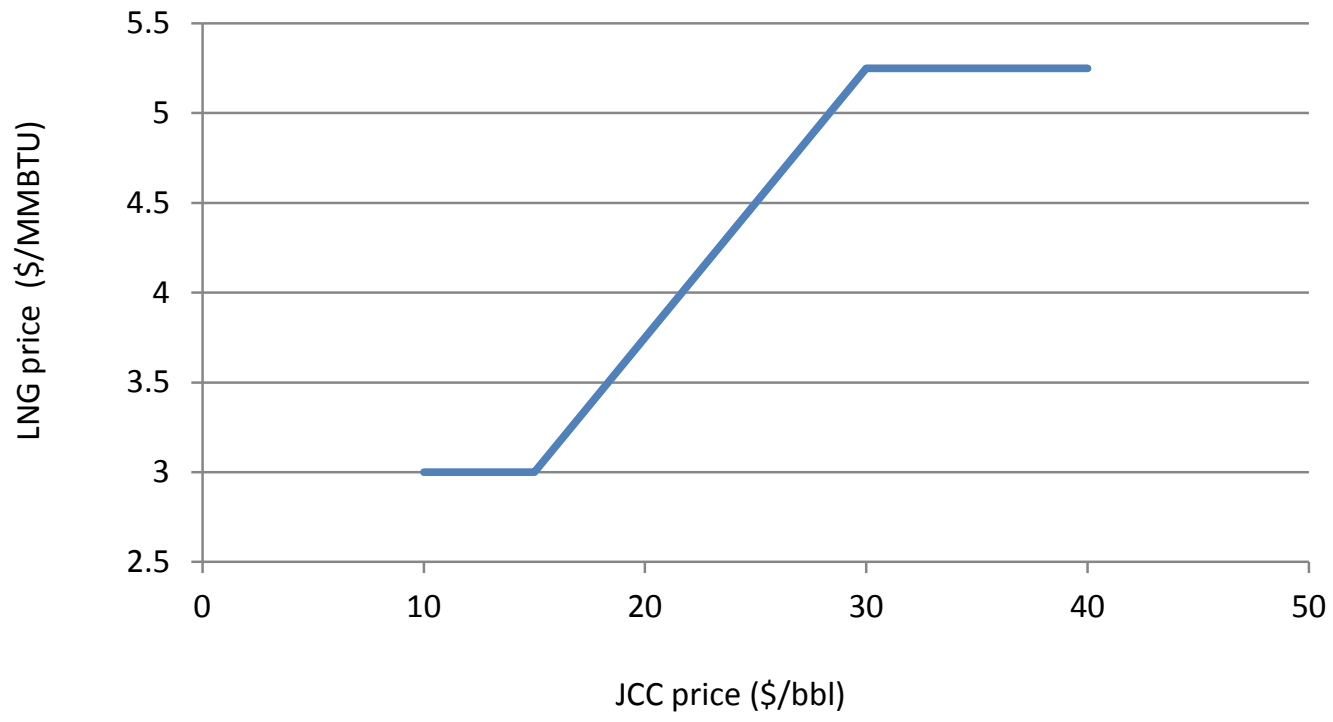

Figure 12 - A typical S-curve (source: Dickel et al., 2007)

The increased prices of oil to more than $100 \$ / \mathrm{bbl}$ since 2010 produced a gap between the oil linked LNG prices, in particular the Asian prices, and the rest of the world (Figure 13). This triggered complainants in Asia, as high LNG prices decrease the industrial competitiveness of the Asian LNG importers, particularly Japan, that heavily rely on LNG as an energy source. As such, Asian LNG importers have been seeking to refine the pricing formula of their LTCs since 2011 . There have also been more radical proposals for total decoupling of Asian LNG prices from oil and establishing an 
Asian LNG Hub, perhaps in Singapore. These proposals are mainly supported by the Japanese government (Rogers and Stern, 2014). However, it is currently expected that in the light of the recent dive in oil prices and the resulting decline in oil linked LNG prices anticipated for 2015 (Meyer et al., 2014), the urge for refining the pricing formulas in Asian LTCs and decoupling the prices from oil will subside (McHugh, 2015).

Note that while LNG spot prices in the US and the UK tend to follow the respective gas market indicators, spot prices in Continental Europe and Asia, where there are no such indicators, can be much higher or lower than LTC prices.

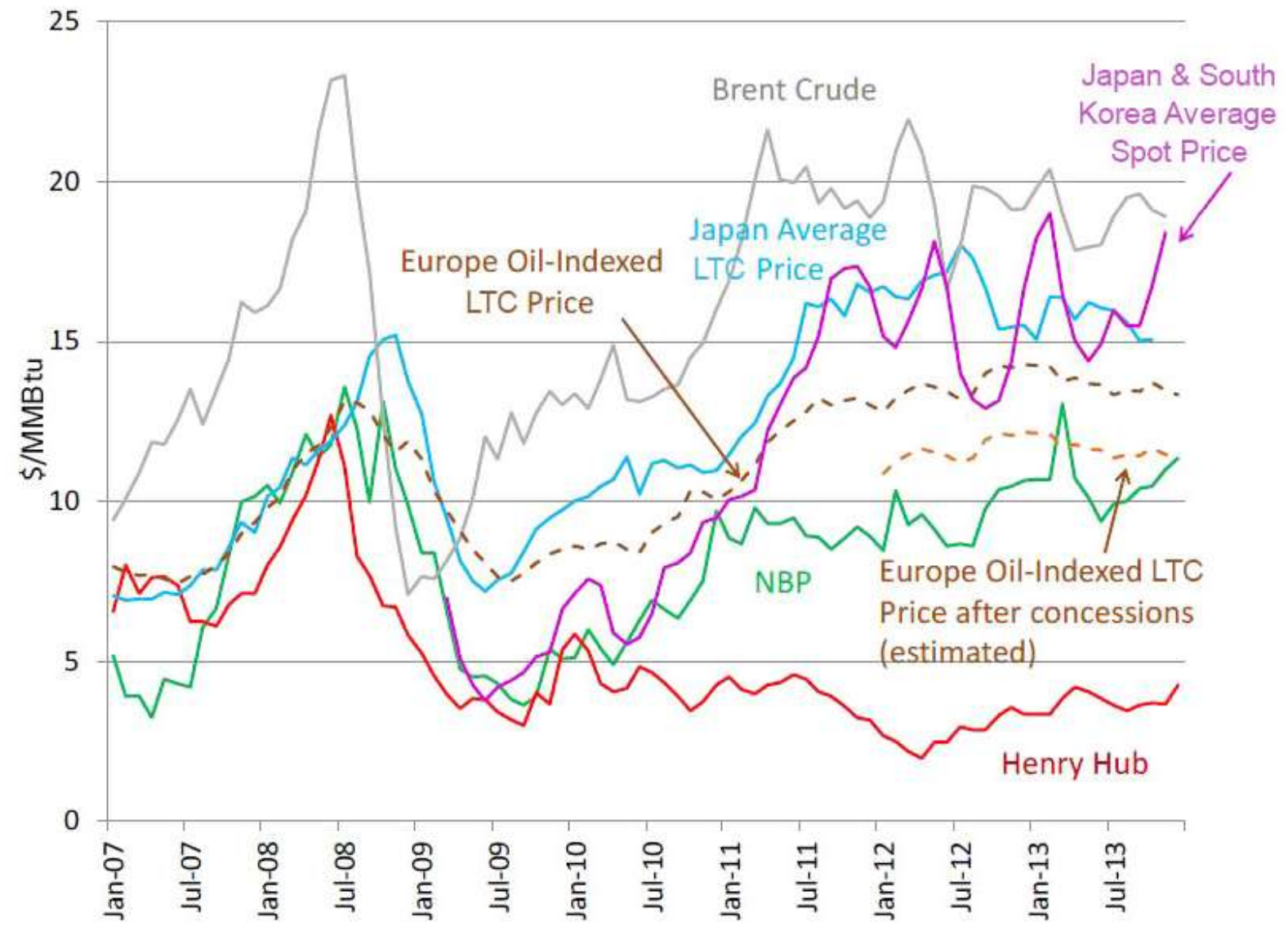

Figure 13 - Regional comparison of monthly average of gas/LNG prices, 2007-2013 (source: Rogers and Stern, 2014)

Overall, given the new LNG supply enterprises coming online in the next a few years, particularly in Australia, that will result in 36\% jump in global LNG liquefaction capacity by 2018 (Almeida, 2014), the restart of some Japanese nuclear power plants in 2015 (Oil Price, 2014), the signals on slowing Chinese economy (Anderlini, 2014) and in addition the prospect of two gas pipelines planned between Russia and China (Homeriki, 2014), it is foreseen that at least for the next five years the balance of the global LNG trade would shift to a buyer's market (Almeida, 2014) with a general decrease in LNG prices expected (Yep, 2014). As such, if the oil prices boost again, the debates on refining the Asian LNG pricing formulas in LTCs and decoupling LNG prices from oil will probably intensify once more. 


\section{CONCLUSIONS AND FURTHER RESEARCH}

This paper provides an analysis of the worldwide LNG trade. Trade flows of LNG are portrayed and main LNG supply regions that are Middle East and North Africa, and Asia-Pacific; also main consumption regions that are Asia and Europe are identified. It also confirms that the regions which are currently the main suppliers and consumers of LNG are likely to remain so for the foreseeable future.

The analysis of the traditional LNG trade demonstrates that the traditional LTCs, and in particular the take-or-pay clause of the contracts, have been integral in risk management and finance of the LNG projects. The case of liberalized and liberalizing gas markets is discussed and it is established that due to changing dynamics of these markets and the resulting risk redistribution in favour of the buyers, the producers are vertically integrating the industry through self-contracting. In addition, the rising importance of LNG spot sales, including arbitrage and uncommitted product sale, is discussed, illustrating the increasing flexibility within the sector. Finally, the pricing of LNG considering the recent fall in oil prices is studied demonstrating that pricing is regional and categorized in two different general groups: prices linked to market indicators in advanced liberalized gas markets, and prices connected to rival energies in other markets; furthermore, for the next a few, it is substantiated that given the shift of trade to a buyer's market, a worldwide decline in LNG prices is expected.

Having analysed the global LNG trade, one may ask: will there be a day that the LNG projects are developed without LTCs? How and when a total decoupling of LNG prices from oil and other rival energies will happen? What will it take for LNG to be sold on forward and futures contracts in commodity markets? What would be the role of cheaper technology and expansion of infrastructure all around the world, in essence increased market liquidity, in moving towards such a state of trade? These are some interesting questions to answer; the writers believe a comparison of oil market development throughout its history with LNG trade will provide very useful insights.

Apart from the international trade of LNG, there are two other topics in the LNG sector which are the subject of great interest: peak-shaving LNG plants and LNG as fuel for transport. Peak-shaving LNG plants, where gas is stored as LNG and regasified and returned to the pipeline in peak times, have been around since 1960s in the US and exist in the UK, Canada, Germany, Norway, China, Australia, Argentina, Belgium, the Netherlands and Japan (Frey et al., 2009). It would be interesting to analyse the business of these plants; i.e. to compare them with rival methods of peak-shaving such as underground gas storages (UGSs); to study the risk and risk management methods, contracts and cost structure of the plants; and to survey the structure through which partners develop such projects also finance them.

LNG as fuel for transport is a much newer topic. This fuel that is cheap, environmentally friendly and enjoys a high energy density, today is considered for all modes of transport, i.e. sea, land and air. Currently some ferries (Lloyd's Register, 2014) and LNG tankers (Adamchak and Adede, 2013) are burning LNG as fuel; the application of LNG in sea transport is in progress along with development of LNG bunkering in ports (ABS, 2014; Gazprom Germania, 2014; Port of Antwerp, 2014). LNG is an excellent fuel for long distance heavy duty trucks; presently China has the biggest network of LNG fuel stations with more than 1,800 stations (Market Watch, 2014). Designs and tests for LNG locomotives are reported (Smith, 2013). Boeing has started working on concepts for LNG fuelled planes, though LNG aircrafts are still a little down the road and probably will come to service in midcentury (Bradley and Droney, 2012).

There are however technical problems associated with the need to keep LNG cool if it is to remain liquid. Evaporation or boil off into the atmosphere needs to be kept to a minimum as the main 
component of natural gas is methane, a potent greenhouse gas. A thorough analysis of LNG driven business in each of the transport modes would expedite the expansion of industrial applications.

\section{ACKNOWLEDGEMENT}

The writers appreciate valuable contributions of Mr Andy Flower to this research. Mr Flower has been working as an independent consultant for the last thirteen years specialising in the LNG trade. He retired from BP in 2001 after 32 years of service, including 22 years working in the company's LNG and natural gas unit where he managed BP's interests in a number of LNG projects. Mr Flower is a senior research fellow in the Oxford Institute for Energy Studies (http://www.oxfordenergy.org /author/andy-flower/).

\section{REFERENCES}

1. ABDULKARIM, R. (2008) What will Allow Gas Production Projects to be Financed in the same way as Oil Projects? Centre for Energy, Petroleum \& Mineral Law \& Policy, University of Dundee. [Online] http://www.dundee.ac.uk/cepmlp/gateway/?news=29854, last retrieved $30 / 08 / 2014$.

2. ABS (2014) Bunkering of Liquefied Natural Gas-fueled Marine Vessels in North America. [Online]

http://www.eagle.org/eagleExternalPortalWEB/ShowProperty/BEA\%20Repository/Referenc es/Capability\%20Brochures/BunkeringReport, last retrieved 30/08/2014.

3. ADAMCHAK, F. \& ADEDE, A. (2013) LNG as Marine Fuel. in $17^{\text {th }}$ International Conference \& Exhibition Liquefied Natural Gas (LNG 17). 16-19 April, Houston, US. [Online] http://www.gastechnology.org/Training/Documents/LNG17-proceedings/Transport-11Fred-Adamchak-Presentation.pdf, last retrieved 30/08/2014.

4. ADEGUN, K. (2006) Take or Pay Contracts as Investment Drivers for Gas Development Projects in Developing Countries: Are there Co Pilots? Centre for Energy, Petroleum \& Mineral Law \& Policy, University of Dundee. [Online] http://www.dundee.ac.uk/cepmlp/gateway/index.php?news=28078, last retrieved $30 / 08 / 2014$.

5. ALMEIDA, I. (2014) BofA Sees Global LNG Entering Multiyear Bear Market on Supplies. [Online] http://www.bloomberg.com/news/2014-12-09/bofa-sees-global-Ing-enteringmultiyear-bear-market-on-supplies.html, last retrieved 20/01/2015.

6. ANDERLINI, J. (2014) China's Growth in Danger of Slowing More Sharply. [Online] http://www.ft.com/cms/s/0/ccb72910-60f1-11e4-894b-00144feabdc0.html, last retrieved 20/01/2015.

7. ANYANWU, W. (2010) The Nature of LNG Arbitrage A Study of Its Theoretical Growth in Global Market. Cyprus International University. [Online] http://www.academia.edu/2627297/The_Nature_of_LNG_Arbitrage_A_Study_of_Its_Theor etical_Growth_in_Global_Market, last retrieved 30/08/2014.

8. ARGUS GLOBAL LNG (2011) Buyer's Market Prompts Contract Changes. Argus Global LNG Monthly, February. [Online] 
http://media.argusmedia.com/ /media/Files/PDFs/Samples/Argus-Global-LNG.pdf, last retrieved 30/08/2014.

9. BG GROUP (2013) LNG - Are the Dynamics Changing? [Online] http://www.bggroup.com/InvestorRelations/Presentations/Documents/LNG-Dynamics-Jan2013.pdf, last retrieved 30/08/2014.

10. BP (2014) BP Statistical Review of World Energy - June 2014. [Online] http://www.bp.com/content/dam/bp/pdf/Energy-economics/statistical-review-2014/BPstatistical-review-of-world-energy-2014-full-report.pdf, last retrieved 30/08/2014.

11. BRADLEY, M. K. \& DRONEY, C. K. (2012) Subsonic Ultra Green Aircraft Research Phase II: N+4 Advanced Concept Developments. NASA (The National Aeronautics and Space Administration), NASA/CR-2012-217556. [Online] http://ntrs.nasa.gov/archive/nasa/casi.ntrs.nasa.gov/20120009038.pdf, last retrieved 30/08/2014.

12. CEER (Council of European Energy Regulators). (2013) CEER Status Review and Evaluation of Access Regimes at LNG Terminals in the EU. [Online] http://www.energyregulators.eu/portal/page/portal/EER_HOME/EER_PUBLICATIONS/CEER_PAPERS/Gas/Tab3/ C12-\%20LNG-15-03_Acces\%20at\%20LNG\%20Terminals_13032013_final_published.pdf, last retrieved 30/08/2014.

13. CHANDRA, V. (2006) Fundamentals of Natural Gas: An International Perspective. Tulsa (OK), PennWell Corp.

14. DAVEY, H. (1997) 'Take or Pay' and 'Send or Pay': A Legal Review and Long-Term Prognosis. Oil and Gas Law Taxation Review, 15(11), 419-422.

15. DAVOUST, R. (2008) Gas Price Formation, Structure \& Dynamics. Paris, Institut Français des Relations Internationales (Ifri). [Online] http://www.ifri.org/downloads/notedavoust.pdf, last retrieved 30/08/2014.

16. DICKEL, R., GÖNÜL, G., GOULD, T., KANAI, M., KONOPLYANIK, A., SELIVANOVA, Y. \& JENSEN, J. (2007) Putting a Price on Energy: International Pricing Mechanisms for Oil and Gas. Brussels, Energy Charter Secretariat. [Online] http://www.encharter.org/fileadmin/user_upload/document/Oil_and_Gas_Pricing_2007_E NG.pdf, last retrieved 30/08/2014.

17. DICKEL, R., PERTSOVICH, V., KANAI, M., JENSEN, J., SELIVANOVA, Y., KHITARISHVILI, T., COOP, G., GÖNÜL, G., SOROKINA, O. \& SAKAMOTO, S. (2008) Fostering LNG Trade: Role of the Energy Charter. Brussels, Energy Charter Secretariat. [Online] http://www.encharter.org/fileadmin/user_upload/Publications/LNG_2008_ENG.pdf, last retrieved 30/08/2014.

18. DREWRY (2010) LNG Shipping Market 2010: Annual Review and Forecast. London, Drewry Shipping Consultants Ltd.

19. EC (European Commission). (2009) Directive 2009/73/EC of the European Parliament and of the Council of 13 July 2009 Concerning Common Rules for the Internal Market in Natural Gas. [Online] http://eurlex.europa.eu/LexUriServ/LexUriServ.do?uri=OJ:L:2009:211:0094:0136:en:PDF, last retrieved $30 / 08 / 2014$. 
20. EIA (Energy Information Administration). (2011) International Energy Outlook 2011. Washington DC, EIA. [Online] http://www.eia.gov/forecasts/ieo/pdf/0484(2011).pdf, last retrieved 30/08/2014.

21. ENCKE, F. (2012) Bringing Gas to the Markets. Brussels, Energy Charter Secretariat. [Online] http://www.encharter.org/index.php?id=584, last retrieved 30/08/2014.

22. ENOBUN, E. (2008) How much of a Threat is Open Market Liberalization to Tradional LNG? and How Concerned Should a Project Lender Be? Centre for Energy, Petroleum \& Mineral Law \& Policy, University of Dundee. [Online] http://www.dundee.ac.uk/cepmlp/gateway/index.php?news=28084, last retrieved $30 / 08 / 2014$.

23. FERC (Federal Energy Regulatory Commission). (2002) Hackberry Decision. [Online] http://www.eia.gov/oil_gas/natural_gas/analysis_publications/ngmajorleg/ferc.html, last retrieved 30/08/2014.

24. FLOWER, ANDY. LNG consultant. (Personal correspondence. 5 May 2013).

25. FREY, E., EISENTROUT, B. \& SNYDER, J. (2009) Efficient Operation in Peak Times. LNG Industry, Winter. [Online]

http://www.cbi.com/images/uploads/technical_articles/Efficient_Operations_at_Peak_Time S_-_LNG_Industry_-_Winter_2009.pdf, last retrieved 30/08/2014.

26. FUIIME, K. (2002) LNG Market and Price Formation in East Asia. The Institute of Energy Economics, Japan. [Online] http://eneken.ieej.or.jp/en/data/pdf/127.pdf, last retrieved 30/08/2014.

27. GAZPROM GERMANIA (2014) The Gazprom Group and Rostock Port Sign Memorandum of Understanding. [Online] https://www.gazprom-germania.de/en/media/media-centre/pressrelease/the-gazprom-group-and-rostock-port-sign-memorandum-of-understanding.html, last retrieved 30/08/2014.

28. GIIGNL (Groupe International des Importateurs de Gaz Natural). (2013) The LNG Industry in 2012. [Online]

http://www.giignl.org/sites/default/files/PUBLIC_AREA/Publications/giignl_the_Ing_industry _2012.pdf, last retrieved 30/08/2014.

29. GONCALVES, C. \& MELLING, A. (2014) Perfect Match? European Natural Gas Markets and North American LNG Exports. Natural Gas and Electricity, 30(8). [Online] http://www.brgexpert.com/media/publication/417_Goncalves_Melling_PerfectMatch_NGE_March2014.pdf , last retrieved 30/08/2014.

30. GREENWALD, G. B. (2006) Natural Gas Contracts under Stress: Price, Quantity and Take or Pay. Oil, Gas \& Energy Law, 4(1), n/a.

31. HARTLEY, P. R. (2013) The Future of Long-Term LNG Contracts. University of Western Australia Business School, discussion paper no. 13.22. [Online] http://www.business.uwa.edu.au/_data/assets/pdf_file/0009/2356524/13-22-The-Futureof-Long-term-LNG-Contracts.pdf, last retrieved 30/08/2014. 
32. HAWK, A., PACHECO-DE-ALMEIDA, G. \& YEUNG, B. (2013) Fast-Mover Advantages: Speed Capabilities and Entry into the Emerging Submarket of Atlantic Basin LNG. Strategic Management Journal, 34(13): 1531-1550.

33. HOLZ, F., RICHTER, P. M., VON HIRSCHHAUSEN, C. (2013) Structural Shift in Global Natural Gas Markets: Demand Boom in Asia, Supply Shock in the US. DIW Economic Bulletin, 3(11/12), 13-20. [Online] http://hdl.handle.net/10419/88612, last retrieved 30/08/2014.

34. HOMERIKI, L. (2014) Russia to Build Second Gas Pipeline to China after Beijing Agreement. [Online]

http://rbth.co.uk/business/2014/11/13/russia_to_build_second_gas_pipeline_to_china_aft er_beijing_agreement_41393.html, last retrieved 20/01/2015.

35. IEA (2012) Gas Pricing and Regulation: China's Challenges and IEA Experience. Paris, IEA. [Online] http://www.iea.org/publications/freepublications/publication/ChinaGasReport_Final_WEB. pdf, last retrieved 30/08/2014.

36. IGU (International Gas Union). (2012) World LNG Report - 2012 Edition. [Online] http://www.igu.org/gas-knowhow/publications/igu-publications/LNG\%20Report\%202011web-7.pdf, last retrieved 30/08/2014.

37. IGU (International Gas Union). (2013) World LNG Report - 2013 Edition. [Online] http://hcbcdn.hidrocarburosbol.netdnacdn.com/downloads/online_version_world_Ing_report_2013_edition_original.pdf, last retrieved 30/08/2014.

38. JENSEN, J. \& DICKEL, R. (2009) Fostering LNG Trade Developments in LNG Trade and Pricing. Brussels, Energy Charter Secretariat. [Online] http://www.encharter.org/fileadmin/user_upload/document/LNG_2009_ENG.pdf, last retrieved 30/08/2014.

39. JENSEN, J. T. (2004) The Development of a Global LNG Market: Is it Likely? If so, When? Oxford Institute for Energy Studies, NG 5. [Online] http://www.oxfordenergy.org/wpcms/wp-content/uploads/2010/11/NG5TheDevelopmentofAGlobalLNGMarketIsItLikelyIfSoWhen-JamesJensen-2004.pdf, last retrieved 30/08/2014.

40. KING \& SPALDING (2004) LNG Import Terminals: Challenges and Opportunities. [Online] http://www.kslaw.com/imageserver/KSPublic/library/event/agenda/Ingmay20041.pdf, last retrieved 30/08/2014.

41. KUMAR, S., KWON, H.-T., CHOI, K.-H., HYUN CHO, J., LIM, W. \& MOON, I. (2011) Current Status and Future Projections of LNG Demand and Supplies: A Global Prospective. Energy Policy, 39(7), 4097-4104.

42. LEE, H. (2005) Dawning of a New Era: The LNG Story. John F. Kennedy School of Government, Harvard University, working paper no. RWP05-053. [Online] http://papers.ssrn.com/sol3/papers.cfm?abstract_id=822356, last retrieved 30/08/2014.

43. LLOYD'S REGISTER (2014) Fincantieri launches North America's first LNG Ferry. [Online] http://www.Ir.org/en/news/news/fincantieri-launches-north-americas-first-Ing-ferry.aspx, last retrieved 30/08/2014. 
44. MARKET WATCH (2014) 4th China Natural Gas Vehicle \& Gas Fueling Station Construction Development Summit to be Held in June. [Online] http://www.marketwatch.com/story/4thchina-natural-gas-vehicle-gas-fueling-station-construction-development-summit-to-be-heldin-june-2014-05-06, last retrieved 30/08/2014.

45. MAXWELL, R. (2007) Unbundled vs. Integrated LNG Chain: What is the Significance of Project Financing the Unbundled Chain Instead of the Integrated LNG Chain? Centre for Energy, Petroleum \& Mineral Law \& Policy, University of Dundee. [Online] http://www.dundee.ac.uk/cepmlp/gateway/index.php?news=29280, last retrieved $30 / 08 / 2014$.

46. MCHUGH, B. (2015) Low Oil Price Makes Any New Liquefied Natural Gas Projects Uneconomical. [Online] http://www.abc.net.au/news/2015-01-07/gas-price-to-fall-in2015/6004676, last retrieved 20/01/2015.

47. MEYER, G., MCLANNAHAN, B. \& HUME, N. (2014) Oil's Dive Set to Transform LNG Market. [Online] http://www.ft.com/intl/cms/s/0/14a5df06-6af1-11e4-ae5200144feabdc0.html\#axzz3PDWLdHSe, last retrieved 20/01/2015.

48. MICHOT FOSS, M. (2007) Introduction to LNG - an Overview on Liquefied Natural Gas (LNG), its Properties, Organization of the LNG Industry and Safety Considerations. Centre for Energy Economics, University of Texas. [Online] http://www.beg.utexas.edu/energyecon/Ing/documents/CEE_INTRODUCTION_TO_LNG_FIN AL.pdf, last retrieved 30/08/2014.

49. MUKHERJEE, K. \& PANANDIKER, R. (2014) LNG - Global Challenges \& Opportunities and Imperatives for India in Petrotech 2014-11 $1^{\text {th }}$ International Oil \& Gas Conference and Exhibition. 12-15 January, Delhi, India. [Online] http://www.bcgindia.com/documents/file152473.pdf, last retrieved 30/08/2014.

50. OIL PRICE (2014) Will Low Oil Prices Shatter LNG Hopes? [Online] http://oilprice.com/Energy/Natural-Gas/Will-Low-Oil-Prices-Shatter-LNG-Hopes.html, last retrieved 20/01/2015.

51. OMORHIRHI, I. (2006) Gas Market Liberalization and Long-Term Gas Sales Contracts: Are They Compatible? Centre for Energy, Petroleum \& Mineral Law \& Policy, University of Dundee. [Online] http://www.dundee.ac.uk/cepmlp/gateway/index.php?news=28094, last retrieved 30/08/2014.

52. OSILIKO, Y. (2005) How Are the Problems of Buyer in Long-Term Take or Pay Contracts in the Gas Industry Mitigated? Centre for Energy, Petroleum \& Mineral Law \& Policy, University of Dundee. [Online] http://www.dundee.ac.uk/cepmlp/gateway/index.php?news=28059, last retrieved 30/08/2014.

53. PIRRONG, C. (2014) Fifty Years of Global LNG: Racing to an Inflection Point. Trafigura Beheer BV, TD/0088.1e. [Online] http://www.trafigura.com/media/1350/fifty-years-global-Ing-craigpirrong-research-trafigura-2.pdf, last retrieved 20/01/2015.

54. PORT OF ANTWERP (2014) Port of Antwerp Plans to Setup LNG Bunkering Station for Barges. [Online] http://www.portofantwerp.com/en/news/port-antwerp-plans-set-Ing-bunkeringstation-barges, last retrieved 30/08/2014. 
55. RADETZKI, M. (1999) European Natural Gas: Market Forces Will Bring About Competition in any Case. Energy Policy, 27(1), 17-24.

56. RAZAVI, H. (1996) Financing Oil and Gas Projects in Developing Countries. Finance and Development, June. [Online] http://www.imf.org/external/pubs/ft/fandd/1996/06/pdf/razavi.pdf, last retrieved $30 / 08 / 2014$.

57. REUTER, M. (2003) Strategic Issues in Structuring and Documenting Liquefied Natural Gas Projects. King \& Spalding. [Online] www.kslaw.com/library/pdf/Strategiclssues_LNG.pdf, last retrieved 30/08/2014.

58. RITZ, R. A. (2013) Price Discrimination and Limits to Arbitrage in Global LNG Markets. Energy Policy Research Group, University of Cambridge, EPRG working paper 1317. [Online] http://www.cambridgeeprg.com/wp-content/uploads/2013/10/1317-PDF.pdf, last retrieved $30 / 08 / 2014$.

59. ROBERTS, P. (2011) Gas Sales and Gas Transportation Agreements: Principles and Practice. 3rd ed. London, Sweet \& Maxwell.

60. ROGERS, H. V. \& STERN, J. (2014) Challenges to JCC Pricing in Asian LNG Markets. Oxford Energy Institute, NG 81. [Online] http://www.oxfordenergy.org/wpcms/wpcontent/uploads/2014/02/NG-81.pdf, last retrieved 30/08/2014.

61. ROGERS, H. V. (2010) LNG Trade-Flows in the Atlantic Basin: Trends and Discontinuities. Oxford Energy Institute, NG 41. [Online] http://www.oxfordenergy.org/wpcms/wpcontent/uploads/2010/11/NG41-

LNGTradeFlowsInTheAtlanticBasinTrendsandDiscontinuities-HowardRogers-2010.pdf, last retrieved 30/08/2014.

62. SATO, N. (2000) Financing International LNG Projects. in 16th World Petroleum Congress. 1115 June, Calgary, Canada. [Online] http://www.onepetro.org/mslib/servlet/onepetropreview?id=WPC-30451, last retrieved $30 / 08 / 2014$.

63. SMITH, K. (2013) LNG: Fuel of the Future? [Online] http://www.railjournal.com/index.php/locomotives/Ing-fuel-of-the-future.html, last retrieved 30/08/2014.

64. TAYLOR-DEJONGH (2004) Market Price Risk: the New Realities and LNG Project Finance Structure. [Online] http://www.taylor-dejongh.com/wpcontent/uploads/2010/07/Financing-LNG-in-a-risky-market.pdf, last retrieved 30/08/2014.

65. TOTAL (2011) Liquefied Natural Gas: A Booming Industry. [Online] http://www.total.com/MEDIAS/MEDIAS_INFOS/5076/EN/TOTAL-liquefied-natural-gas.pdf, last retrieved 30/08/2014.

66. UBS (2004) Introduction to the Oil Industry. [Online] http://ypenergy.net/attachments/files/ubs.pdf, last retrieved 30/08/2014.

67. WEEMS, P. \& SULIVAN, H. (2005) LNG Overview. Short Course on International Energy Law, Contracts and Negotiations 2005. [Online] http://www.kslaw.com/library/pdf/2005shortcourse.pdf, last retrieved 30/08/2014. 
68. WEEMS, P. R. \& HWANG, M. (2013) Overview of Issues Common to Structuring, Negotiating and Documenting LNG Projects. Journal of World LNG Law and Business, 6(4): 267-299.

69. YEGOROV, Y. \& DEHNAVI, J. (2012) Is LNG Arbitrage Possible in Natural Gas Market? United States Association for Energy Economics, working paper no. 2110234. [Online] http://papers.ssrn.com/sol3/papers.cfm?abstract_id=2110234, last retrieved 30/08/2014.

70. YEP, E. (2014) Asian LNG Buyers Bet on Growing Supply, Evolving Markets. [Online] http://blogs.wsj.com/moneybeat/2014/09/24/asian-Ing-buyers-bet-on-growing-supplyevolving-markets/, last retrieved 20/01/2015.

71. ZHURAVLEVA, P. (2009) The Nature of LNG Arbitrage: An Analysis of the Main Barriers to the Growth of the Global LNG Arbitrage Market. Oxford Institute for Energy Studies, NG 31 [Online] http://www.oxfordenergy.org/wpcms/wp-content/uploads/2010/11/NG31TheNatureofLNGArbitrageAndAnAnalysisoftheMainBarriersfortheGrowthofGlobalLNGArbitr ageMarket-PolinaZhuravleva-2009.pdf, last retrieved 30/08/2014. 